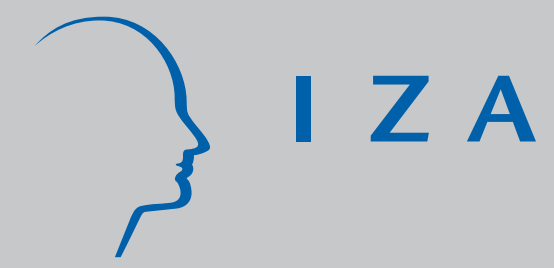

IZA DP No. 1354

Heterogeneity in the Intergenerational Transmission of Educational Attainment: Evidence from Switzerland on Natives and Second Generation Immigrants

Philipp Bauer

Regina T. Riphahn

October 2004 


\title{
Heterogeneity in the Intergenerational Transmission of Educational Attainment: Evidence from Switzerland on Natives and Second Generation Immigrants
}

\author{
Philipp Bauer \\ University of Basel \\ Regina T. Riphahn \\ University of Basel, \\ DIW Berlin and IZA Bonn

\section{Discussion Paper No. 1354 \\ October 2004}

\author{
IZA \\ P.O. Box 7240 \\ 53072 Bonn \\ Germany \\ Phone: +49-228-3894-0 \\ Fax: +49-228-3894-180 \\ Email: iza@iza.org
}

\begin{abstract}
Any opinions expressed here are those of the author(s) and not those of the institute. Research disseminated by IZA may include views on policy, but the institute itself takes no institutional policy positions.

The Institute for the Study of Labor (IZA) in Bonn is a local and virtual international research center and a place of communication between science, politics and business. IZA is an independent nonprofit company supported by Deutsche Post World Net. The center is associated with the University of Bonn and offers a stimulating research environment through its research networks, research support, and visitors and doctoral programs. IZA engages in (i) original and internationally competitive research in all fields of labor economics, (ii) development of policy concepts, and (iii) dissemination of research results and concepts to the interested public.
\end{abstract}

IZA Discussion Papers often represent preliminary work and are circulated to encourage discussion. Citation of such a paper should account for its provisional character. A revised version may be available directly from the author. 
IZA Discussion Paper No. 1354

October 2004

\section{ABSTRACT \\ Heterogeneity in the Intergenerational Transmission of Educational Attainment: Evidence from Switzerland on Natives and Second Generation Immigrants*}

This study applies rich data from the 2000 Swiss census to investigate the patterns of intergenerational education transmission for natives and second generation immigrants. The level of secondary schooling attained by youth aged 17 is related to their parents' educational outcomes using data on the entire Swiss population. Based on economic theories of child educational attainment we derive hypotheses regarding the patterns in intergenerational education transmission. The data yields substantial heterogeneity in intergenerational transmission across population groups. Only a small share of this heterogeneity is explained by the predictions of economic theory.

JEL Classification: $\quad$ I21, J61

Keywords: intergenerational transmission, educational attainment, second generation immigrants

Corresponding author:

Regina T. Riphahn

WWZ

University of Basel

Petersgraben 51

4003 Basel

Switzerland

Email: Regina.Riphahn@unibas.ch

\footnotetext{
* We acknowledge the financial support from the Swiss Nation Science Foundations NRP 52 "Childhood, Youth, and Intergenerational Relationships" grant. We thank Holger Bonin, Axel Engellandt, Horst Entorf, George Sheldon, and the participants of the IZA AM ${ }^{2}$ meeting 2004 for helpful comments on earlier versions and Reto Scherrer for excellent research assistance.
} 


\section{Introduction}

Child education and labor market outcomes are affected by their parents' characteristics. This phenomenon has been investigated in a wide theoretical and empirical literature. However, research on the heterogeneity and patterns of intergenerational transmission is only in its infancy. A few studies compare earnings and education transmission across countries ${ }^{1}$ and all acknowledge the relevance of parental background for child educational attainment. However, evidence on the potential heterogeneity of parental education effects e.g. for various population groups under given institutional frameworks is limited. Using data from Switzerland we address two issues. First, we investigate to what extent intergenerational education transmission differs across population groups. Then we examine whether the predictions of economic theory can contribute to explain the patterns of intergenerational education transmission.

The relevant literature provides two types of analyses: one group of studies compares intergenerational education transmission for natives and immigrants. ${ }^{2}$ These studies do not address the heterogeneity of education transmission across other population groups and provide no explanation for the observed patterns. Another group of studies focuses on the explanation of intergenerational transmission trying to identify the effect of parental education separately from genetic effects. This literature has used evidence from twins or adopted children as well as

${ }^{1}$ See e.g. Couch and Dunn (1997), Bjorklund and Jäntti (1997), Checchi et al. (1999) and most recently Woessmann (2004) and Entorf and Minoiu (2004).

${ }^{2}$ Card et al. (2000) find that in the United States educational mobility has been consistently higher among the children of immigrants. Gang and Zimmermann (2000) conclude that in Germany the parental education of immigrants does not affect child outcomes. Leslie and Drinkwater (1999) and Sweetman and Dicks (1999) confirm the relevance of intergenerational education transmission for the U.K. and Canada. Van Ours and Veenman (2003) conclude that natives and immigrants do not differ in intergenerational educational transmission. Nielsen et al. (2003) suggest that second generation immigrants in Denmark are educationally more mobile than natives. 
instrumental variable techniques. ${ }^{3}$ In contrast and since our data does not allow us to separate nature and nurture effects, we follow a non-structural approach that does not differentiate between genetic and behavioral determinants of intergenerational transmission. Instead we estimate the combined effect. ${ }^{4}$

The importance of parental characteristics for child education is stressed e.g. by Belzil and Hansen (2003), who find that family background variables account for up to 85 percent in the explainable variation in child school attainment. Also, Woessmann (2004) points out that the explanatory power of parental background measures in models of educational outcomes dwarfs the effects of school inputs and institutional features. These findings challenge current systems of education transmission and their equal opportunities record. This is significant as capital markets do not provide funds for human capital investments at the secondary schooling level. If in response to this evidence on the important role of parental characteristics - educational policy intends to provide equal educational opportunities and to strengthen educational upward mobility it must know whether, how, and why the observed intergenerational transmission patterns vary across population groups. $^{5}$

The OECD's study on pupils' educational outcomes (PISA) yielded that across 31 participating countries the impact of parents' socioeconomic status on child educational outcomes was nowhere as large as in Switzerland (OECD 2002). By international comparison, the Swiss educational system appears to favor the children of the better off. Typically, the offspring of

${ }^{3}$ See e.g. Behrman and Rosenzweig (2002), Plug (2004), Björklund et al. (2004), or Chevalier (2004).

${ }^{4}$ Woessmann (2004) takes the same approach. Ermisch and Francesconi (2001) provide a rationale based on which the parameters thus obtained can be interpreted as causal effects as opposed to intergenerational correlations.

${ }^{5}$ As an example of the risks of uninformed educational policies, Machin (2004) shows that the expansion of the British education system in the 1970s and 1980s caused a decline in educational mobility and disproportionately benefited the children of the rich. 
immigrants are not in that group. Yet, the economic impact of immigration depends on the assimilation of these youths. Therefore it is important to know whether intergenerational mobility provides a bridge allowing disadvantaged children to catch up, and for which population groups such a bridge exists.

To address these questions we use the year 2000 census of Switzerland, which provides interesting data. First, Switzerland has a large population share of immigrants: as of 2000, 21.3 percent of the Swiss population were foreign born and a similar share did not have Swiss citizenship. Second, the data covers the entire resident population of 7.5 million individuals. Finally, Swiss educational policies are run by 26 regional administrative units, the cantons. While the educational institutions are similar across cantons, regulatory details differ. Since the dataset is sufficiently large we can control for such cantonal differences and regional effects.

After describing the heterogeneity in education transmission across population groups we test whether economic models of educational attainment contribute to an explanation of the observed patterns. We investigate whether (i) higher costs of schooling are correlated with lower educational mobility, (ii) parents' quantity-quality tradeoff regarding educational investments also affects educational mobility, and (iii) country of origin characteristics and ethnic capital affect the intergenerational transmission of education.

We find substantial differences in the magnitude of intergenerational transmission across population groups. Upward mobility is higher for females than males and for second generation immigrants than native Swiss. When investigating possible determinants of educational mobility, we find confirmation for the impact of direct and opportunity costs. Particularly for immigrants and for children of well educated natives the probability of educational upward mobility declines as the number of siblings rises. Ethnic capital and home country characteristics do not seem to explain the heterogeneity in intergenerational education transmission. 


\section{Background Information, Literature and Hypotheses}

Immigration to Switzerland: Topped only by Luxembourg, Switzerland has the highest population share of foreigners in the OECD (OECD 2004). The origins of this high share reach back to the 1950s and 1960s when Switzerland - similar to other European countries - attracted foreign workers to solve its labor shortage. Already then Swiss immigration law differentiated between seasonal workers, workers with annual permits, and permanent immigrants. Seasonal workers who returned to Switzerland regularly could obtain annual permits and holders of annual permits, who had stayed in Switzerland for five years, could apply for permanent permits. Over time many former seasonal workers acquired rights to stay in Switzerland. ${ }^{6}$

In addition to these blue collar guest workers who typically arrived from southern Europe, Switzerland has always attracted highly skilled foreign workers: in 2003 only 30 percent of native employees had tertiary training compared to 58 percent of all immigrants from northern and western Europe (BFS 2004b). In the early 1990s, Switzerland also received a significant number of refugees and asylum seekers adding to the foreign born population.

Educational System: In Switzerland children enter primary school typically between ages 5 and 7 and stay there for between 4 and 6 years. Subsequently, they move on to mandatory schools until they completed 9 years of schooling. In some cantons mandatory schools differentiate pupils able to follow a basic and an advanced program.

After the first 9 years, at the age of 14-16, pupils choose whether and how to continue their education. ${ }^{7}$ They can continue their general education at advanced schools which after about 3 years grant the degree required for university studies. The vast majority takes up an

${ }^{6}$ The share of permanent residents in the foreign population increased from about 10 percent in the early 1960s to 38 percent 1970, and 72 percent in 2000 (BFS 1988, 2004a).

${ }^{7}$ For a descriptive study of the transition after mandatory school see Amos et al. (2003). 
apprenticeship lasting between two and four years which prepares for a vocational career. Alternatively, there are a variety of vocational or general schools which either train for particular occupations or prepare for more specialized schools. These vocational schools are heterogeneous in requirements and organization.

In this study we compare youth based on their education at age 17, when we can determine which educational route they have taken: Out of the cohort which left mandatory school in 2000, after two years 21 percent were enrolled in advanced school, 64 percent were in apprenticeships, 4 percent attended vocational schools, while the others did not pursue training (Hupka 2003). ${ }^{8}$

Theory and Literature: The literature provides three theoretical approaches to explain educational attainment levels: The first states that optimal schooling is attained when marginal costs and benefits of further education balance. Optimal schooling investment should decline with higher cost and increase with rising benefits. The argument was first developed by Becker (1967) and has been expanded on by numerous authors (e.g. Becker and Tomes 1986, Ermisch and Francesconi 2002, Han and Mulligan 2001). Chiswick (1988) applied it to the case of ethnic groups which may differ in the evaluation of the marginal costs and benefits of education.

The second, closely related approach argues that parents face an implicit tradeoff between the number of children and the amount invested in each (Becker and Lewis 1973). With given resources parents can either have many children in which they invest little, or they can have few children of higher "quality" demanding e.g. educational investments. Since the opportunity cost of caring for children is higher for highly educated parents, theory predicts not only a negative

${ }^{8}$ Our data provide very similar distributions. Hupka (2003) also presents the distribution across training pathways by parental socioeconomic status: among the children of parents in the bottom quartile of the status distribution only 6 percent attend advanced school, compared to 48 percent among children of parents in the top quartile. A comparison by migration status shows only minor differences between natives and second generation immigrants. 
correlation between child quantity and the level of educational investment in each, but also that highly educated parents invest more in each of their (few) children. The evidence on these predictions is mixed. Chiswick (1988), Sweetman and Dicks (1999), or Ermisch and Francesconi (2001) confirm a negative correlation between the number of siblings and educational attainment. In contrast, Wolter and Coradi Vellacott (2002) find negative correlations between child quantity and educational attainment for families of low socio-economic status and positive correlations in native families with high status in Switzerland. Bauer and Gang (2001) find insignificant sibling effects for German samples.

Finally, Borjas $(1992,1995)$ argues that the availability of ethnic capital, modeled as the average skill level in the parent generation of a child's ethnic group, supports the educational attainment of immigrant youth. The evidence from other studies is mixed: Nielsen et al. (2003) and Riphahn (2004) find no confirmation for such correlations in Danish and German data. Gang and Zimmermann (2000) find a positive correlation between the size of an ethnic group at the time the youth was aged 6 and immigrants' subsequent educational attainment.

The theoretical approaches described above suggest that the level of education declines with cost and the number of siblings, and increases if immigrants enjoy high supplies of ethnic capital. We are interested not only in the level of educational attainment, but in its intergenerational transmission, i.e. in educational mobility. We model the educational attainment $(\mathrm{Y})$ of child $\mathrm{i}$ as a function of parental education (PE) and other characteristics (X) including e.g. indicators of cost and siblings:

$$
\mathrm{Y}_{\mathrm{i}}=\mathrm{a}+\mathrm{b} \mathrm{PE}_{\mathrm{i}}+\mathrm{c} \mathrm{X}_{\mathrm{i}}+\epsilon_{\mathrm{i}}
$$

where $\mathrm{a}, \mathrm{b}$, and c could be coefficients and $\epsilon$ represents unobservable factors. The above theories then provide hypotheses regarding the sign of c. While numerous studies have investigated equations such as (1) this study shifts attention from the determinants of levels of education (Y) to the determinants of intergenerational transmission, i.e. educational mobility. Educational 
mobility is measured by the impact of parental education on child education, in the case of equation (1) reflected by $\partial \mathrm{Y} / \partial \mathrm{PE}=\mathrm{b}$. The larger $\mathrm{b}$, the lower educational mobility and the more child educational outcomes depend on parental education. ${ }^{9}$

We know from the literature cited above (cf. Footnote 3 ) that three types of factors may determine educational mobility: genetics, parental behavior, and environmental factors. While studies such as Plug (2004) or Björklund et al. (2004) focus on the genetic and behavioral effects, we take the composite parental effect as given and investigate the relevance of environmental factors for intergenerational educational mobility. Among the environmental factors which may affect educational transmission outcomes we consider those which are also hypothesized to shift the level of educational outcomes: education costs, siblings, and ethnic capital. We investigate, whether the level of intergenerational mobility (b) varies with these variables (S), which are a subset of the vector of characteristics $\mathrm{X}$, by estimating

$$
Y_{i}=a+b E_{i}+c X_{i}+d\left(P E_{i} \cdot S_{i}\right)+\epsilon_{i}
$$

and evaluating $\partial \mathrm{Y} / \partial \mathrm{PE}=\mathrm{b}+\mathrm{d} \cdot \mathrm{S}$. A significant estimate of $\mathrm{d}$ then indicates significant heterogeneities in intergenerational mobility across the outcomes of S. While the extant literature on intergenerational transmission merely considered educational mobility as a constant, we investigate whether it varies depending on environmental factors $\mathrm{S}$.

Why should the determinants of educational levels also affect educational mobility? The intuition of our argument is that parents of a given educational level may be more able to support their children in attaining high levels of education if costs are low and not many children are to be supported. ${ }^{10}$ Given the budget and liquidity constraints of the investing household, the negative effect of having poorly educated parents for an individual's educational opportunities

${ }^{9}$ In studies, which instead of parental education focus on indicators of social status, $b$ is at times labelled the 'socioeconomic gradient.'

${ }^{10}$ For a similar argument see Woessmann (2004) who investigates the heterogeneity of intergenerational transmission across levels of child ability. 
may grow as environmental conditions turn disadvantageous (e.g. higher education cost, more siblings, less ethnic capital): the opportunity to balance the disadvantage of poorly educated parents by other resources such as intensified parental attention disappear.

To operationalize our hypotheses we need to define the set of environmental characteristics $\mathrm{S}$. We use two measures of education costs. The literature provides evidence that the distance to educational institutions affects the cost of attending school (see e.g. Fuller et al. 1982, Ordovensky 1995, or Sa et al. 2004). Assuming that low population density is correlated with higher distance and that higher distance implies higher cost of education we expect lower levels of educational attainment and smaller intergenerational mobility in rural areas.

As a second measure of education costs high youth unemployment should imply lower opportunity cost of education. Leslie and Drinkwater (1999) found that youth with higher unemployment probabilities were more likely to take up continued education and Goldin (1998) finds higher secondary school graduation rates in states with worse youth employment opportunities. Therefore we expect higher education and upward mobility in situations of high youth unemployment.

The quantity-quality model suggests that children with few siblings have better educational opportunities. Since the number of siblings may affect the impact of parental education on youth outcomes and how much parents of a given educational level are able to support a child, we expect higher educational upward mobility for children of parents with few rather than many siblings.

Finally, we investigate the relevance of ethnic capital effects with respect to educational mobility and estimate the influence of the number of highly educated co-ethnics in the region on child educational attainment and on intergenerational mobility. ${ }^{11}$ Also, we hypothesize that

${ }^{11}$ We also considered the number of co-ethnics, the share of highly educated co-ethnics, and the number of highly educated co-ethnics. All measures were generated both on the national and the regional level. The chosen indicator is closest to Borjas (1992) concept of ethnic capital 
characteristics of immigrants' source countries may affect educational attainment in Switzerland (cf. Borjas 1993 for a similar argument): if first generation immigrants originate in a country with low average education this may increase the probability that their children exceed the educational attainment of their parents, as - due to poor home country educational opportunities - even high ability parents are more likely to be in low education groups.

\section{Empirical Approach and Data Description}

\subsection{Empirical Approach}

We start the analysis by considering descriptive statistics of intergenerational education transmission for subsamples of natives and immigrants. Then we apply multivariate regressions to evaluate the determinants of the levels of child educational attainment. Besides indicators of parental education (PE), we control for household characteristics $(\mathrm{H})$ such as parental occupational status, age, and the number of siblings. Among the controls for personal characteristics of the youth (I) we consider sex and religious affiliation. A last group of control variables describes the region of residence $(\mathrm{R})$ using seven geographical indicators, population density in the community of residence, and the cantonal youth unemployment rate. ${ }^{12}$ The baseline model for the native sample with the latent variable $\mathrm{Y}_{\mathrm{i}}^{*}$ describing youth education is

$$
\mathrm{Y}_{\mathrm{i}}^{*}=\alpha+\beta \mathrm{PE}_{\mathrm{i}}+\gamma_{1} \mathrm{H}_{\mathrm{i}}+\gamma_{2} \mathrm{I}_{\mathrm{i}}+\gamma_{3} \mathrm{R}_{\mathrm{i}}+\epsilon_{\mathrm{i}}
$$

where the, $\alpha, \beta$, and $\gamma_{1}-\gamma_{3}$ are coefficients, and $\epsilon_{\mathrm{i}}$ is a random error. The $\beta$ coefficients inform about the correlation between parent and youth education and thus about educational mobility.

Finally, we test whether the correlation between parent and youth educational attainment differs significantly by environmental characteristics such as the cost of education or the number of siblings. We consider appropriate interaction effects of parental education $(\mathrm{S} \cdot \mathrm{PE})$ in the

and yielded the clearest results.

${ }^{12} \mathrm{H}$, I, and R can be considered subsets of the previously specified covariate vector X. 
model, and estimate the additional coefficients $\beta_{1}$ :

$$
\mathrm{Y}_{\mathrm{i}}^{*}=\alpha_{0}+\beta_{0} \mathrm{PE}_{\mathrm{i}}+\beta_{1}\left(\mathrm{~S}_{\mathrm{i}} \cdot \mathrm{PE}_{\mathrm{i}}\right)+\gamma_{1} \mathrm{H}_{\mathrm{i}}+\gamma_{2} \mathrm{I}_{\mathrm{i}}+\gamma_{3} \mathrm{R}_{\mathrm{i}}+\epsilon_{\mathrm{i}}
$$

In the estimations for the second generation immigrant subsample we control for immigrant specific covariates (M). These include the parental naturalization status, whether an individual's main language differs from the municipal language, and indicators of region of origin. Also, we consider as an indicator of ethnic capital the number of highly educated coethnics in a person's region in Switzerland. Just as for natives we test our hypotheses regarding heterogeneities in intergenerational education transmission by adding interaction terms of parent education to the model. The equations estimated for immigrants are identical to (3) and (4) except for the additional set of immigrant specific covariates, M. Based on the estimation results for natives and second generation immigrants we perform simulation experiments to evaluate the relevance of environmental factors $(\mathrm{S})$ for intergenerational education transmission.

We cannot exclude the possibility that unobserved factors and characteristics of households are correlated with both, our dependent variable of child educational outcomes and the environmental factors $(\mathrm{S})$ which we are interested in. In that case our parameter estimates do not yield causal effects of environmental factors but also reflect the impact of the unobserved mechanisms. Since we have no instruments available to address this problem with the available data, we interpret our results as descriptive and indicative of correlation patterns rather than as clean measures of causal mechanisms. The former are nevertheless interesting and informative as our data, first, are representative of the entire population and second, allow for more detailed controls of observable covariates than previous studies in this field.

\subsection{Data Description}

Data and Sample: The Swiss census of 2000 covers the entire resident population and provides information on sociodemographic indicators such as family structure, migration status, education, 
occupation, religion, and language. To learn about education transmission we need information on child and parent educational attainment. Since the questionnaire does not ask individuals about the educational attainment of their parents, we can relate child to parent education only if we match co-resident parents and children using information on household composition. We focus on youth aged 17 because the majority of these teenagers still lives in the parental household and because we can distinguish educational attainment and schooling choices most clearly at age 17 .

In order to allow for the correct identification of a youth's parent we dropped those households from the sample where two household heads were of the same sex ${ }^{13}$ and restricted the sample to those 17 year olds who indicated to be child of the head of household. This excludes youths who live in the home of relatives other than their parents. To match the "correct" parent to a child, we require that the parent must be at least 14 years older than this child, the parent must indicate to have children, and the parent's variable 'birthyear of child' must be identical to the child's year of birth. Finally, we consider only those youths for whom we have information on their current educational attainment. Out of a total of 87,135 17 year olds in the data these conditions leave us with 74,147 observations. ${ }^{14}$

To investigate the heterogeneity in intergenerational transmission by immigrant status we define two subsamples: (a) natives are those Swiss born youths who have at least one Swiss born parent and for whom no parent was born abroad. (b) Second generation immigrants are those Swiss born individuals who have at least one foreign born parent. Our sample contains 47,948

${ }^{13}$ Since the youth's status in the household is only indicated as child of head of household we would not be certain which of the same sex partners would be the true parent.

${ }^{14}$ Out of the difference of 12,988 youths 4.8 percent were lost due to same sex household heads, 72.3 percent because the youth did not indicate to be child of the head of the household possibly because they lived by themselves already - and for about 19.4 percent of the lost 17 year olds we could not match their true parents. For about 453 youth (or 3.5 percent) we had no information on their current level of schooling. 
natives, and 14,587 second generation immigrants. ${ }^{15}$

Dependent Variable: Based on the educational system described above, our outcome variable describes low, middle, and high educational attainment. The educational attainment of those who at age 17 have not completed mandatory education or who are not currently pursuing any continued education is considered to be low. Those who completed mandatory school and continue with vocational training or any school but advanced school have medium education. Only those pursuing advanced secondary schooling or who entered university already are considered to be highly educated. Since our dependent variable describes educational attainment as an ordered categorical outcome measure we apply ordered probit estimators.

Table 1 describes our sample by educational attainment separately for males and females: While a smaller share of females has a medium level of education, they are more likely to be enrolled in advanced school or to have low education. Among second generation immigrants we find a higher share of enrollees in advanced school and in low education than among natives.

Explanatory Variables: The most important explanatory variables describe parental education. Similar to the indicators for youth education, we coded three education levels for parents based on the highest degree obtained. Since not all youths lived with both parents and education information is missing for some parents, parental education is coded in five categories of high, middle, low, no response, and missing parent. The distribution of parental education by sex and ethnic group is provided in the first rows of Table 2: Mothers have lower attainments than fathers both among natives and second generation immigrants. The latter have higher shares of high and

\footnotetext{
${ }^{15}$ We defined first generation immigrants as those born abroad with at least one foreign born parent and combined all remaining individuals in the "other" group. The data contained 10,142 first generation immigrant youths and 1,460 of the "other" group. Particularly the former have lower educational attainments than the samples analysed here.
} 
low educational attainment, with smaller shares in the middle, more nonresponse, and fewer missing parents.

The summary statistics for the other control variables in the native and second generation immigrant models are also presented in Table 2. A number of indicators show substantially different means for the two subsamples. ${ }^{16}$ The observed native and immigrant parents are of similar age and fertility. The parents of second generation immigrants appear to have worse occupational positions than natives'. Immigrants seem to be somewhat concentrated in the Italian and French speaking regions of the country. They live in more densely populated regions with higher unemployment rates. The largest share originates in southern European countries. ${ }^{17}$ For only nine percent of the observations does the personal main language not match the main language of the municipality. Ideally, and following up on a large literature (cf. Corak et al. 2004) one would control for parental income as a determinant of child educational outcome. Since this variable is not available in the census we use parents' occupational position as proxy.

\section{Results}

\subsection{Description of Intergenerational Educational Transmission}

Table 3 (Panels A and B) provides the transition matrices of child and parent educational attainments separately for natives and second generation immigrants. Disregarding the first two columns in each block we find that the probability of low education given that either parent is of low education is higher for second generation immigrants (Panel B) than for natives (Panel A). However, the probability of high education given lowly educated parents (i.e. of educational upward mobility) is much higher for second generation immigrants than for natives (15.47

${ }^{16}$ However, not all reflect factual differences because the values for missing parents in single-parent households are set to zero, and enter the calculation of the means.

${ }^{17}$ The single largest ethnic group in this sample are Italian youth (1987 individuals) followed by those from former Yugoslavia (618), Turkey (615), Spain (531), and Portugal (253). 
percent with respect to fathers, 14.95 percent with respect to mothers versus 7.53 and 9.53 percent for natives). There are only minor mobility differences with respect to fathers vs. mothers. The risk of downward mobility to low education is somewhat higher for children of well educated immigrants than natives.

Panel $\mathrm{C}$ of Table 3 describes the probability of advanced school enrollment conditional on parental education for native and second generation immigrant subsamples. The first row yields that native children of highly educated fathers attend advanced school with a probability of 62.0 percent, which compares to less than eight percent for native children of lowly educated fathers. The patterns are similar with respect to mothers' attainments. The next two rows yield higher probabilities of high education for girls than for boys.

In order to quantify the role of parental education for the child's probability of high education we provide two measures: columns (4) and (8) indicate the absolute difference between the probability of advanced school enrollment for children of lowly and highly educated parents. Columns (5) and (9) indicate how much more likely the child of a highly educated parent is to reach high education than the child of a lowly educated parent. The smaller both figures, the more equal and the less dependent on parental education are educational opportunities.

Among natives the probability of high education is about eight times higher if the father is of high rather than low education. The role of mothers' education is somewhat smaller. Both parents appear to have larger impacts on their sons' than on their daughters' attainment. By all measures, parental impact among second generation immigrants is smaller than among natives however with comparable patterns. Compared to natives, second generation immigrants show much higher upward mobility in columns (2) and (6).

The next rows inform about the differences in educational mobility by language region: educational upward mobility is highest in the Italian and lowest in the German language regions. It may be that the high upward mobility in the Italian speaking municipalities is driven by 'mean 
reversion', i.e. a catching up process regarding advanced school participation, and thus regionally deviating time trends. Figure 1 illustrates the educational expansion by language region for the birth cohorts of 1920-1978. This suggests that mean reversion is not a plausible explanation as advanced school participation levels have been high in Italian speaking regions. Possibly, the traditionally intense use of vocational training in the German language region explains the low educational upward mobility in these regions.

The next entries in Panel C compare the educational mobility for children of single parents with those of two-parent families. Among natives we observe 2,239 17 year olds in single father and 9'809 in single mother families. Independent of parental education these youths' opportunities of attaining high degrees are worse than those of youths living in double parent households. Upward mobility is particularly low for youth living in single father families. For single mother families the probabilities of attaining high educational degrees are low and the impact of parental education is about average (cf. columns (8) and (9)).

When sorting second generation immigrants by country of origin we find vast differences in child educational attainment and a wide spread of parental influence over the regions of origin. Next, we use years since taking on Swiss citizenship as an indicator of immigrant assimilation and differentiate four subsamples of second generation immigrant youth by parental citizenship status: educational opportunities are worst for those youth whose parents do not hold Swiss citizenship. Interestingly, even for those worst off among the second generation immigrants the chances of exceeding their parents' education are higher than for natives.

Panel D of Table 3 describes intergenerational education transmission for subsamples as suggested by the hypotheses spelled out above. We find the expected differences in the probability of high education based on the hypothesized cost effects: natives with lowly educated fathers have a probability of 9 percent to be highly educated in densely populated areas and of only 7 percent in regions where we expect high costs of commuting. The probability of attending 
advanced school for the group with low educated fathers is at 13 percent in regions of high unemployment where opportunity costs of education are low and at 6 percent where opportunity costs are high. The patterns are confirmed when fathers are highly educated, when mothers' education is considered instead, and for the sample of second generation immigrants.

Panel D also supports the hypothesized sibling effects: for native and immigrant parents with low education we observe a higher probability of high educational attainment for children with few siblings. The patterns are less clear for families with highly educated parents.

The ethnicity effects are somewhat mixed. The evidence supports the ethnic capital hypothesis, i.e. youth with many highly educated co-ethnics have better opportunities of attaining high educational degrees. The hypothesis of higher upward mobility for children of low educated parents from countries with low levels of average education are not supported.

These results indicate that the level of intergenerational education transmission is indeed heterogeneous. Below we investigate whether economic theory can contribute to explain some of these observed differences.

\subsection{Estimation Results: Baseline Model}

Before discussing the heterogeneity in intergenerational educational mobility we briefly describe our baseline estimates for the levels of native and second generation immigrant educational attainment. The marginal effects of the ordered probit estimations for the two subsamples are presented in Table 4. For coefficients and standard errors see the Appendix.

As expected, we find highly significant marginal effects of parental education. For natives having a father with low education increases the probability of child low education by 3.6 percentage points, which is substantial compared to the average predicted rate of 6.9 percent. Having a highly educated father reduces the probability of low education outcomes by 5.3 percentage points. As the marginal effects of maternal education are similar, this indicates the 
large impact of parental education for youth outcomes. The patterns are comparable for immigrants where the relative magnitudes of the marginal effects are not as large.

The correlation patterns across parental occupational positions follow expectations. Generally, the children of fathers or mothers in high occupational positions enjoy probabilities of high educational attainment which are about 10 percentage points above those of the reference group of the unemployed. ${ }^{18}$

Confirming prior studies we find positive correlations of child educational attainment with parental age (see e.g. Nielsen et al. 2003 or Ermisch and Francesconi 2001). For natives, the coefficients describing sibling effects are jointly significant at the eight percent level. The marginal effects suggest only small educational disadvantages for youths with many siblings. The correlation patterns are much more significant in the immigrant sample where having three or more siblings reduces the probability of high educational outcomes by about 6 percentage points.

Females are significantly more likely to attend advanced school than males, with a marginal effect of four percentage points for natives and about six for immigrants. Among natives all religious groups do worse educationally than the reference group of christians. Also, in the immigrant sample the religion controls are jointly highly significant.

The population density in a municipality does not yield significant marginal effects even though the marginal effect in the native sample is of substantial magnitude in the expected direction. The significant youth unemployment effects confirm that educational attainment increases with unemployment. Both effects are identified from cross-sectional comparison across cantons, where we control for seven geographic regions. We find significant regional differences in educational attainment, with the highest attainment in Ticino.

Among the immigrant specific variables the assimilation indicators controlling for parent

${ }^{18}$ Among natives there are no beneficial effects of having a father in a low level blue collar position or out of the labor force. In contrast, among second generation immigrants, children of these fathers perform significantly better than those with unemployed fathers. 
naturalization are not jointly significant. Only for children of parents who naturalized within the last 5 years do we find significantly higher probabilities of high education compared to the reference group of the most assimilated children. The country of origin effects are jointly significant and indicate that compared to immigrants from Southern Europe those from (North and Western) Europe and Western Asia have significantly lower educational outcomes. As expected not speaking the municipal language is correlated with lower education. We find no significant effects of the average educational level in the country of origin except for the missing data indicator. While the ethnic capital effect is statistically significant, it is of small magnitude and indicates the opposite of the expected effect.

In sum, we find confirmation for the theoretically predicted level effect of education costs and sibling size, but not for that of ethnic capital. In order to interpret the magnitude of the overall intergenerational transmission effects and the explanatory power of the covariates, we performed simulation experiments separately for natives and second generation immigrants: based on the above estimations we predicted the probability of high educational attainment for the full sample conditional on both parents being either in the high, medium, or low education category (see the first two columns of Table 4C). The average probabilities of advanced school attendance differ strongly depending on parental background, even after controlling for the other covariates. The impact of parental education is larger for natives than for second generation immigrants: for natives the predicted probabilities of attaining high education differ by 48.5 percentage points depending on parental education compared to 37 percentage points for immigrants.

In the last two columns of Table $4 \mathrm{C}$ we present the simulation results that obtain when the same simulations are based on estimations which control only for parental education. The bottom two lines show that in this case the predicted impact of parental education is much larger. For both subsamples, the explanatory variables therefore account for about one third of the 
differences in predicted educational attainment by parental education.

\subsection{Estimation Results: Heterogeneity}

After describing these baseline results and determinants of the level of youth educational attainment we now focus on the heterogeneity in intergenerational education transmission. Our first hypothesis suggests that education transmission may be affected by education costs.

We reestimated the baseline models of Table 4 first with complete interactions of population density with parental education and then with complete interactions of youth unemployment and parental education. Table 5A presents the results of subsequent simulation experiments performed separately for natives and second generation immigrants. ${ }^{19}$ The first row indicates that the interaction terms were jointly highly statistically significant in the estimations for the native sample but not for the second generation immigrant sample. This suggests significant differences in educational mobility based on cost differences for natives.

We expect that the probability of high educational attainment is higher in regions with high population density and high youth unemployment. Among natives this is confirmed for children of parents with middle and high education. Surprisingly, for children of parents with low education we find higher probabilities of high education in sparsely populated regions and in regions of low unemployment. Also, and contrary to expectations, we find a smaller impact of parental education for natives in rural areas and in regions with low unemployment (see the bottom rows of Panel A). Among immigrants, where the estimations did not yield precisely estimated coefficients, the expected patterns obtain. ${ }^{20}$

${ }^{19}$ The coefficient estimates of this and subsequently discussed interaction effects are not presented to save space. The probability of high educational attainment was again predicted after setting the education of both parents jointly to either low, middle, or high.

${ }^{20}$ Similar results were obtained when grouping regions by an urban-rural classification as provided by BFS (1997). 
With respect to the number of siblings we expect higher educational success among those with few siblings and reduced educational upward mobility as family sizes increase. Again we estimated ordered probit regressions for natives and immigrants with full interactions between indicators of parent education and indicators of the number of siblings. The 24 coefficients of the interaction terms were jointly significant only for the immigrant sample. The simulations in Table 5B yield some confirmation for the hypothesis that educational success is more likely in families with few children. For natives this is most clearly the case for parents of middle and high education. We have no explanation for the result that youth without siblings has a comparatively low probability of high education. ${ }^{21}$ For the immigrant sample, the role of parental education increases with the number of siblings and as expected, upward educational mobility declines with a rising number of siblings (see Table 5B).

Finally, we investigate ethnic capital effects in the simulations of Table 5C. The ethnic capital hypothesis suggests that second generation immigrants enjoy better educational opportunities if their ethnic group in the host country is well educated. We defined three measures of ethnic capital: the number of co-ethnics, the share of co-ethnics with high education, and the total number of highly educated co-ethnics. The estimations yielded similar results for all indicators: the main effects indicate a negative correlation between ethnic capital and educational outcomes and the interaction effects of ethnic capital with parental education are insignificant. Contrary to expectations the predicted probability of high educational attainment is higher for those with little ethnic capital, independent of parental education.

As a second ethnicity effect we expected higher upward mobility for youth from countries

${ }^{21}$ This outcome does not appear in educational transition matrices calculated separately by the number of siblings. The hypothesis that the effect is due to a concentration of single parents in the group of one child families was rejected in separate estimations for dual parent families only, as well. Interestingly, Wolter and Coradi Vellacott (2002) find the same correlation pattern for Swiss PISA outcomes by number of siblings. Also, Black et al. (2004) strongly confirm this pattern with data on the entire population of Norway. 
with low average educational attainment. We coded a number of national education measures such as the illiteracy, primary, secondary, tertiary enrollment rate, and the internet user rate. ${ }^{22}$ Generally, the results were similar to the effects of the illiteracy rate presented in Table 5C: the interaction effects are marginally significant. The simulations yield only minor differences in the education and mobility outcomes across the different types of countries of origin.

In sum, not all effects of environmental factors on intergenerational transmission support the hypotheses laid out above. For natives the estimations indicate significant differences in intergenerational education transmission depending on the costs of education. Among second generation immigrants intergenerational transmission is significantly affected by the number of siblings and country of origin characteristics. The simulations generally yield effects in the expected direction with respect to education costs and sibling size. However, we find no evidence for the relevance of ethnic capital and only small effects of country of origin characteristics.

In order to evaluate the robustness of our findings we estimated the model for the educational outcomes of the children of low educated parents applying a multinomial logit estimator. The marginal effects of selected covariates on the probability of attaining a high educational degree and thus - for these subsamples - on upward educational mobility are presented in Table 6. While not all of the coefficients and marginal effects are statistically significant, they confirm that the results previously obtained using the ordered probit framework are robust to the choice of the estimation approach: higher costs of education and a large number of siblings tend to reduce the probability of high educational attainment for the children of low educated parents, and the effects are larger for immigrants.

\footnotetext{
${ }^{22}$ The data are taken from the CIA database (www.cia.gov/cia/publications/factbook/).
} 


\section{Conclusions}

We investigate patterns of intergenerational correlation in educational attainment across subsamples of the Swiss population based on the 2000 census. Evidence from prior studies suggests that intergenerational mobility is particularly low in Switzerland (OECD 2002, Woessmann 2004). Our results can be interpreted as evidence for this outcome as we find substantial correlations of child-parent educational outcomes. Among natives seven percent of the children of low educated fathers attend advanced school compared to 62 percent of the children of highly educated fathers. Similar to the situation in other countries (e.g. Card et al. 2000 for the United States) intergenerational mobility is higher among second generation immigrants: having a high versus a low educated father increases the probability of high education for natives by a factor of eight and for second generation immigrants by a factor of four. ${ }^{23}$ However, even for the children of immigrants and after controlling for various characteristics, the probability of high education among those with poorly educated parents is only one third of those with well educated parents. This indicates that there are only limited opportunities for disadvantaged children to catch up educationally.

What may explain the inequalities in educational outcomes and the disadvantage of the children of low educated parents? We find that about one third of the parental education effect is accounted for by the control variables considered in our baseline model, i.e. by regional variables and other characteristics of households with lowly educated parents. This leaves substantial inequities unaccounted for. Economic theory suggests that direct and opportunity costs as well as the number of siblings may be important determinants of the level of educational

${ }^{23}$ Interestingly, Entorf and Minoiu (2004) show that the positive correlation between socioeconomic background and child educational performance in some countries is larger for native (e.g. New Zealand, the U.S., and U.K.) and in others for immigrant children (e.g. Sweden, Finland). Similarly, the correlation between parental origin and child educational outcome in some cases favors the children of natives (e.g. France, Finland, Sweden) and in others those of immigrants (Australia, Canada, the U.S.). 
attainment. We evaluate whether these factors affect intergenerational mobility by estimating interaction effects of parental education in our baseline model of child educational outcomes.

Estimations and simulations confirm that education costs significantly affect the intergenerational transmission patterns and reduce educational upward mobility. Having a large number of siblings is correlated with a reduced probability of both, high educational attainment and educational upward mobility particularly for the sample of second generation immigrants: the probability of high educational attainment declines by almost one third from 21 to 15 percent for children of lowly educated parents if they have three instead of no or only one sibling. Confirming prior studies for Germany and Denmark, we find no evidence for Borjas' (1992, 1995) hypothesis of ethnic capital externalities in immigrant educational outcomes for Switzerland.

While the costs of education and family size generally affect educational attainment and intergenerational education transmission, our results show that even in situations of low costs and few siblings the impact of parental education is considerable. Therefore the environmental determinants of educational mobility investigated here play only a limited role.

This is the first study to focus on differences in intergenerational education transmission across population groups in a given education system and to provide measures of their magnitude. Further research will examine whether institutional features of the schooling system or other environmental factors more successfully explain the transmission differences across population groups. Given its importance for educational policy, intergenerational education transmission, its heterogeneities and determinants deserve further research attention. 


\section{Bibliography}

Amos, Jacques, Edi Böni, Mario Donati, Sandra Hupka, Thomas Meyer, and Barbara E. Stalder, 2003, Wege in die nachobligatorische Ausbildung. Die ersten zwei Jahre nach Austritt aus der obligatorischen Schule Zwischenergebnisse des Jugendlängsschnitts TREE, Bildungsmonitoring Schweiz, Bundesamt für Statistik, Neuchâtel.

Bauer, Thomas and Ira Gang, 2001, Sibling Rivalry in Educational Attainment: The Germany Case, Labour 15(2), 237-255.

Becker, Gary S., 1967, Human Capital and the Personal Distribution of Income: An Analytical Approach, Woytinski Lecture No. 1, Institute of Public Administration, University of Michigan, reprinted in Becker (1993).

Becker, Gary S. and H. Gregg Lewis, 1973, On the Interaction Between Quantity and Quality of Children, Journal of Political Economy 81(2, Part 2), S279-S288.

Becker, Gary S., and Nigel Tomes, 1986, Human Capital and the Rise and Fall of Families, Journal of Labor Economics 4(3), S1

Behrman, Jere and Mark Rosenzweig, 2002, Does increasing women's schooling raise the schooling of the next generation?, American Economic Review 92, 323-334.

Belzil, Christian, and Jörgen Hansen, 2003, Structural Estimates of the Intergenerational Education Correlation, Journal of Applied Econometrics 18, 679-696.

BFS (Bundesamt für Statistik), 1988, Statistisches Jahrbuch der Schweiz 1989, Zürich.

BFS (Bundesamt für Statistik), 1997, Die Raumgliederung der Schweiz, Neuchatel.

BFS (Bundesamt für Statistik), 2004a, Statistisches Jahrbuch der Schweiz 2004, Zürick.

BFS (Bundesamt für Statistik), 2004b, Pressemitteilung: Vermehrte Zuwanderung hochqualifizierter Arbeitskrärfte, Neuenburg 16.02.2004.

Björklund, A. and Jäntti M., 1997, Intergenerational income mobility in Sweden compared to the United States, American Economic Review 87(5), 1009-1018.

Björklund, A., Mikael Lindahl, and Erik Plug, 2004, Intergenerational Effects in Sweden: What Can We Learn from Adoption Data?, IZA Discussion Paper No. 1194.

Black, Sandra, Paul Devereux, and Kjell G. Salvanes, 2004, The More the Merrier? The Effect of Family Composition on Children's Education, mimeo.

Borjas, George J., 1992, Ethnic capital and intergenerational mobility, Quarterly Journal of Economics 107(1), 123-150.

Borjas, George J., 1993, The Intergenerational Mobility of Immigrants, Journal of Labor Economics 11(1,pt.1), 113-135.

Borjas, George J., 1995, Ethnicity, Neighborhoods, and Human-Capital Externalities, American Economic Review 85(3), 365-390. 
Card, David, John DiNardo, and Eugena Estes, 2000, The more things change: immigrants and the children of immigrants in the 1940s, the 1970s, and the 1990s, in: Borjas, George C. (ed.) Issues in the Economics of Immigration, University of Chicago Press, 227-269.

Checchi, D., Andrea Ichino, and Rustichini, 1999, More equal but less mobile? Education financing and intergenerational mobility in Italy and in the US, Journal of Public Economics 74(3), 351-393.

Chevalier, Arnaud, 2004, Parental Education and Child's Education: A Natural Experiment, IZA Discussion Paper No. 1153, Bonn.

Chiswick, Barry R., 1988, Differences in Education and Earnings across Racial and Ethnic Groups: Tastes, Discrimination, and Investments in Child Quality, Quarterly Journal of Economics 103(3), 571-597.

Corak, Miles, Garth Lipps, and John Zhao, 2004, Family Income and Participation in Post-Secondary Education, IZA Discussion Paper No. 977, Bonn.

Couch, K.A. and Dunn, T.A., 1997, Intergenerational correlation in labor market status: a comparison of the United States and Germany, Journal of Human Resources 22(1), 210-232.

Entorf, Horst and Nicoleta Minoiu, 2004, What a Difference Immigration Law Makes: PISA results, migration background, and social mobility in Europe and traditional countries of immigration, IZA Discussion Paper No. 1021, Bonn.

Ermisch, John and Marco Francesconi, 2001, Family Matters: Impacts of Family Background on Educational Attainments, Economica 68(270), 137-156.

Ermisch, John and Marco Francesconi, 2002, Intergenerational Social Mobility and Assortative Mating in Britain, IZA Discussion Paper No. 465, Bonn.

Fuller, Winship C., Charles F. Manski, and David A. Wise, 1982, New evidence on the economic determinants of postsecondary schooling choices, Journal of Human Resources 17(4), 477-498.

Gang, Ira N. and Klaus F. Zimmermann, 2000, Is Child Like Parent. Educational Attainment and Ethnic Origin, Journal of Human Resources 35(3), 550-569.

Galton, Francis, 1889, Natural Inheritance, London, Macmillan.

Goldin, Claudia, 1998, America's Graduation from High School: The Evolution and Spread of Secondary Schooling in the Twentieth Century, Journal of Economic History 58(2), 345-374.

Han, Song and Casey B. Mulligan, 2001, Human capital, heterogeneity and estimated degrees of intergenerational mobility, Economic Journal 111, 207-243.

Hupka, Sandra, 2003, Ausbildungssituation und -verläufe: Übersicht, in: Amos J., et al. (eds.) Wege in die nachobligatorische Ausbildung. Die ersten zwei Jahre nach Austritt aus der obligatorischen Schule Zwischenergebnisse des Jugendlängsschnitts TREE, Bildungsmonitoring Schweiz, Bundesamt für Statistik Neuchâtel, 33-58.

Leslie, Derek and Stephen Drinkwater, 1999, Staying on in Full-Time Education: Reasons for Higher Participation Rates Among Ethnic Minority Males and Females, Economica 66(261), 63-77. 
Machin, Stephen J., 2004, Education Systems and Intergenerational Mobility, Paper presented at the CESifo / PEPG Conference on Schooling and Human Capital Formation in the Global Economy, September 2004, Munich.

Nielsen, Helena Skyt, Michael Rosholm, Nina Smith, and Leif Husted, 2003, The school-to-work transition of 2nd generation immigrants in Denmark, Journal of Population Economics 16(4), 755-786.

OECD, 2002, Education at a Glance. OECD Indicators 2002, OECD, Paris.

OECD, 2004, Trends in international migration. Continuous reporting system on migration: Annual report (SOPEMI), OECD, Paris.

Ordovensky, J. Farley, 1995, Effects of institutional attributes on enrolment choice: implications for postsecondary vocational education, Economics of Education Review 14(4), 335-350.

Plug, Eric, 2004, Estimating the Effect of Mother's Schooling on Children's schooling useing a Sample of Adoptees, American Economic Review, forthcoming.

Riphahn, Regina T., 2004, Are There Time Trends in the Educational Attainment of Second Generation Immigrants, mimeo, University of Basel.

Sa, Carla, R.J.G.M. Florax, and P. Rietveld, 2004, Determinants of the regional demand for higher education: a gravity model approach, Regional Studies 38(4), 373-390.

Sweetman, Arthur and Gordon Dicks, 1999, Education and Ethnicity in Canada. An Intergenerational Perspective, Journal of Human Resoures 34(4), 659-696.

van Ours, Jan C. and Justus Veenman, 2003, The educational attainment of second-generation immigrants in The Netherlands, Journal of Population Economics 16(4), 739-753.

Woessmann, Ludger, 2004, How Equal Are Educational Opportunities? Family Background and Student Achievement in Europe and the United States, CESifo Working Paper No. 1162, Munich.

Wolter, Stefan C. and Maja Coradi Vellacott, 2002, Sibling Rivalry: A Look at Switzerland with PISA Data, IZA Discussion Paper No. 594, Bonn. 
Figure 1 Share of Advanced School Graduates by Birth Cohort and Language Region

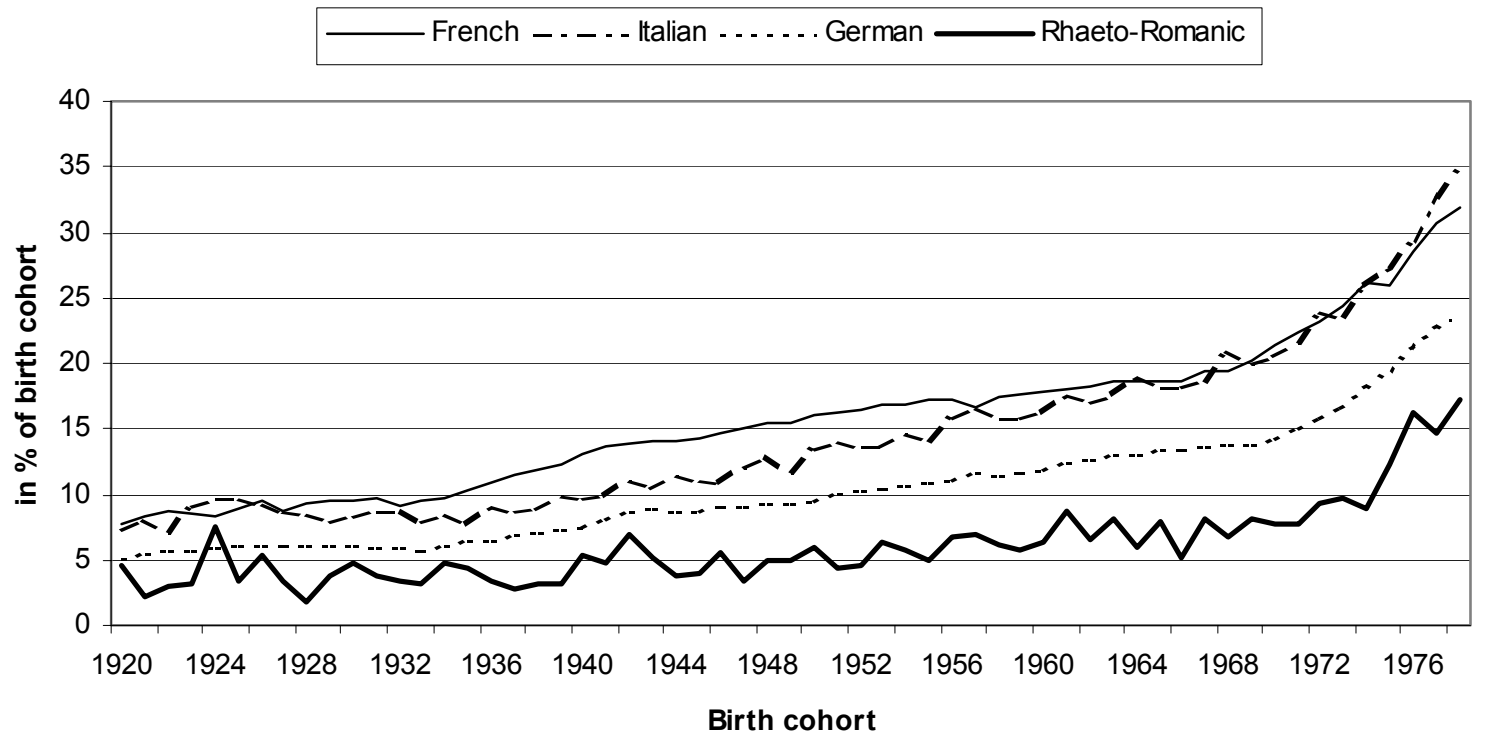

Source: $\quad$ Own calculations based on Census 2000 . 
Table 1: $\quad$ Child Educational Attainment by Group and Sex of Youths Aged 17

\begin{tabular}{lrrrr}
\hline & \multicolumn{2}{c}{ Natives } & \multicolumn{2}{c}{ Second Generation Immigrants } \\
& Male & Female & Male & Female \\
\hline Low (in \%) & 7.71 & 9.57 & 14.55 & 14.47 \\
Medium (in \%) & 73.09 & 62.74 & 60.29 & 49.99 \\
High (in \%) & 19.20 & 27.69 & 25.16 & 35.53 \\
\hline Total (in \%) & 100.00 & 100.00 & 100.00 & 100.00 \\
\hline N. observations & 24,775 & 23,173 & 7,568 & 7,019 \\
N. obs. by group & 47,948 & & 14,587 & \\
\hline
\end{tabular}

Source: $\quad$ Own calculations using Swiss Census 2000. 
Table 2: Descriptive Statistics on Explanatory Variables by Subsample

\begin{tabular}{|c|c|c|c|c|}
\hline & \multicolumn{2}{|c|}{ Natives } & \multicolumn{2}{|c|}{$\begin{array}{l}\text { Second } \\
\text { Generation } \\
\text { Immigrants }\end{array}$} \\
\hline & Mean & Std.Dev. & Mean & Std.Dev. \\
\hline \multicolumn{5}{|l|}{ Parental Education } \\
\hline Father Low $(0 / 1)$ & 0.081 & 0.273 & 0.260 & 0.438 \\
\hline Father Medium (0/1) (Reference) & 0.612 & 0.487 & 0.405 & 0.491 \\
\hline Father High $(0 / 1)$ & 0.093 & 0.290 & 0.151 & 0.358 \\
\hline Father No Response $(0 / 1)$ & 0.009 & 0.096 & 0.034 & 0.182 \\
\hline Father Missing $(0 / 1)$ & 0.205 & 0.403 & 0.150 & 0.357 \\
\hline Mother Low $(0 / 1)$ & 0.189 & 0.392 & 0.350 & 0.477 \\
\hline Mother Medium (0/1) (Reference) & 0.698 & 0.459 & 0.429 & 0.495 \\
\hline Mother High $(0 / 1)$ & 0.050 & 0.217 & 0.140 & 0.347 \\
\hline Mother No Response $(0 / 1)$ & 0.017 & 0.128 & 0.046 & 0.209 \\
\hline Mother Missing (0/1) & 0.047 & 0.211 & 0.035 & 0.184 \\
\hline \multicolumn{5}{|l|}{ Household Characteristics } \\
\hline Father Occ. Position: Unemployed (0/1) (Reference) & 0.005 & 0.067 & 0.018 & 0.132 \\
\hline Father Occ. Position: No training $(0 / 1)$ & 0.028 & 0.166 & 0.124 & 0.329 \\
\hline Father Occ. Position: Low qualified blue collar (0/1) & 0.075 & 0.264 & 0.069 & 0.254 \\
\hline Father Occ. Position: Low qualified white collar $(0 / 1)$ & 0.072 & 0.258 & 0.055 & 0.229 \\
\hline Father Occ. Position: Intermediate level occup. (0/1) & 0.178 & 0.383 & 0.126 & 0.332 \\
\hline Father Occ. Position: Other self employed (0/1) & 0.154 & 0.360 & 0.094 & 0.291 \\
\hline Father Occ. Position: Academic / upper mngmt. (0/1) & 0.107 & 0.309 & 0.095 & 0.293 \\
\hline Father Occ. Position: Qualified self employed (0/1) & 0.022 & 0.146 & 0.024 & 0.153 \\
\hline Father Occ. Position: Top management (0/1) & 0.030 & 0.172 & 0.031 & 0.174 \\
\hline Father Occ. Position: Not employed (0/1) & 0.017 & 0.128 & 0.054 & 0.226 \\
\hline Father Occ. Position Other $(0 / 1)$ & 0.108 & 0.310 & 0.160 & 0.366 \\
\hline Mother Occ. Position: Unemployed (0/1) (Reference) & 0.016 & 0.127 & 0.037 & 0.189 \\
\hline Mother Occ. Position: No training $(0 / 1)$ & 0.078 & 0.268 & 0.156 & 0.363 \\
\hline Mother Occ. Position: Low qualified blue collar (0/1) & 0.019 & 0.137 & 0.012 & 0.108 \\
\hline Mother Occ. Position: Low qualified white collar (0/1) & 0.234 & 0.423 & 0.168 & 0.374 \\
\hline Mother Occ. Position: Intermediate level occup. (0/1) & 0.101 & 0.301 & 0.087 & 0.281 \\
\hline Mother Occ. Position: Other self employed (0/1) & 0.061 & 0.240 & 0.045 & 0.207 \\
\hline Mother Occ. Position: Academic / upper mngmt.(0/1) & 0.022 & 0.146 & 0.033 & 0.179 \\
\hline Mother Occ. Position: Qualified self employed (0/1) & 0.004 & 0.060 & 0.007 & 0.080 \\
\hline Mother Occ. Position: Top management (0/1) & 0.005 & 0.070 & 0.008 & 0.090 \\
\hline Mother Occ. Position: Not employed (0/1) & 0.222 & 0.416 & 0.226 & 0.418 \\
\hline Mother Occ. Position: Other $(0 / 1)$ & 0.191 & 0.393 & 0.187 & 0.390 \\
\hline Father Age & 38.232 & 19.873 & 41.437 & 18.175 \\
\hline Mother Age & 42.951 & 10.432 & 43.837 & 9.738 \\
\hline No Siblings (0/1) (Reference) & 0.070 & 0.255 & 0.085 & 0.279 \\
\hline One Sibling $(0 / 1)$ & 0.455 & 0.498 & 0.504 & 0.500 \\
\hline Two Siblings $(0 / 1)$ & 0.311 & 0.463 & 0.285 & 0.451 \\
\hline Three or more Siblings $(0 / 1)$ & 0.164 & 0.370 & 0.126 & 0.332 \\
\hline \multicolumn{5}{|l|}{ Individual Characteristics } \\
\hline Female $(0 / 1)$ & 0.483 & 0.500 & 0.481 & 0.500 \\
\hline Religion: Christian (0/1) (Reference) & 0.912 & 0.283 & 0.775 & 0.417 \\
\hline
\end{tabular}


Religion: Jewish (0/1)

Religion: Islamic $(0 / 1)$

Religion: Other or no denomination $(0 / 1)$

Religion: No response (0/1)

\section{Regional Characteristics}

Population Density (inhabitants per $100 \mathrm{~km}^{2}$, in 1000)

Cantonal Youth Unemployment Rate 1999

Region $1=\mathrm{VD}, \mathrm{VS}, \mathrm{GE}(0 / 1)$

Region $2=\mathrm{BE}, \mathrm{FR}, \mathrm{SO}, \mathrm{NE}, \mathrm{JU}(0 / 1)$

Region $3=\mathrm{BS}, \mathrm{BL}, \mathrm{AG}(0 / 1)$

Region $4=\mathrm{ZH}(0 / 1)$

Region 5 = GL, SH, AR, AI, SG, GR, TG (0/1)

Region $6=\mathrm{LU}, \mathrm{UR}, \mathrm{SZ}, \mathrm{OW}, \mathrm{NW}, \mathrm{ZG}(0 / 1)$

Region $7=$ TI $(0 / 1)$

Municipal Language German (0/1) (Reference)

Municipal Language French (0/1)

Municipal Language Italian $(0 / 1)$

Municipal Language Rhaeto-Romanic (0/1)

\section{Immigrant Characteristics}

Max. parental assim.: Swiss since birth (0/1) (Reference)

Max. parental assim.: Swiss since at least 5 years $(0 / 1)$

Max. parental assim.: Swiss since up to 5 years $(0 / 1)$

Max. parental assimilation: No Swiss citizenship (0/1)

Country of origin: Africa (0/1)

Country of origin: (Northern and Eastern) Europe (0/1)

Country of origin: Southern Europe (0/1)

Country of origin: Western Europe (0/1) (Reference)

Country of origin: Western Asia (0/1)

Country of origin: Latin America (0/1)

Country of origin: North America (0/1)

Country of origin: Asia and Oceania (0/1)

Country of origin: Other $(0 / 1)$

Main Language differs from municipal language (0/1)

Home country illiteracy rate

Home country illiteracy rate missing $(0 / 1)$

Number of highly educated compatriots (in 1,000 )

$\begin{array}{llll}0.001 & 0.034 & 0.008 & 0.087 \\ 0.002 & 0.048 & 0.072 & 0.258 \\ 0.073 & 0.260 & 0.129 & 0.336 \\ 0.012 & 0.108 & 0.016 & 0.126\end{array}$

$\begin{array}{llll}0.009 & 0.014 & 0.018 & 0.024\end{array}$

$\begin{array}{llll}2.091 & 0.710 & 2.450 & 0.839\end{array}$

$\begin{array}{llll}0.129 & 0.335 & 0.237 & 0.425\end{array}$

$\begin{array}{llll}0.269 & 0.443 & 0.170 & 0.375\end{array}$

$\begin{array}{llll}0.136 & 0.343 & 0.148 & 0.355\end{array}$

$\begin{array}{llll}0.140 & 0.347 & 0.176 & 0.381\end{array}$

$\begin{array}{llll}0.180 & 0.385 & 0.142 & 0.349\end{array}$

$\begin{array}{llll}0.120 & 0.325 & 0.065 & 0.246\end{array}$

$\begin{array}{llll}0.026 & 0.159 & 0.063 & 0.243\end{array}$

$\begin{array}{llll}0.788 & 0.409 & 0.636 & 0.481\end{array}$

$\begin{array}{llll}0.179 & 0.384 & 0.297 & 0.457\end{array}$

$\begin{array}{llll}0.028 & 0.164 & 0.065 & 0.246\end{array}$

$\begin{array}{llll}0.005 & 0.073 & 0.002 & 0.045\end{array}$

\begin{tabular}{llll}
- & - & 0.452 & 0.498 \\
- & - & 0.137 & 0.343 \\
- & - & 0.044 & 0.206 \\
- & - & 0.367 & 0.482 \\
- & - & 0.047 & 0.211 \\
- & - & 0.072 & 0.258 \\
- & - & 0.449 & 0.497 \\
- & - & 0.249 & 0.433 \\
- & - & 0.067 & 0.250 \\
- & - & 0.032 & 0.175 \\
- & - & 0.016 & 0.127 \\
- & - & 0.049 & 0.216 \\
- & - & 0.019 & 0.138 \\
- & - & 0.089 & 0.285 \\
- & - & 5.231 & 10.056 \\
- & - & 0.090 & 0.286 \\
- & - & 2.347 & 3.168 \\
\hline 47,948 & \multicolumn{3}{c}{14,587} \\
\hline
\end{tabular}

Note: Northern Europe: $\quad$ Scandinavian Countries, UK, Ireland, Baltic States

Eastern Europe: $\quad$ Bulgaria, Poland, Rumania, Hungary, Slovakia, Czech Republic, Moldova, Russia, Ukraine, Belarus

Western Europe: $\quad$ Belgium, Germany, France, Liechtenstein, Luxemburg, Monaco, Netherlands, Austria

Southern Europe: $\quad$ Former Yugoslavia, Albania, Greece, Italy, Portugal, Spain

Western Asia:

Turkey, Cyprus, Middle Eastern and Gulf countries, Armenia, Azerbaijan, Georgia.

Source: $\quad$ Own calculations using Swiss Census 2000.

Table 3 Descriptive Analysis of Intergenerational Education Mobility 
Panel A Transition Matrices for Natives (in column percent)

\begin{tabular}{|c|c|c|c|c|c|c|c|c|c|c|c|}
\hline \multirow{2}{*}{$\begin{array}{l}\text { Child } \\
\text { education }\end{array}$} & \multirow{2}{*}{$\begin{array}{l}\text { No } \\
\text { Father }\end{array}$} & \multicolumn{4}{|c|}{ Father's Education } & \multirow{2}{*}{$\begin{array}{c}\text { No } \\
\text { Mother }\end{array}$} & \multicolumn{4}{|c|}{ Mother's Education } & \multirow[t]{2}{*}{ Total } \\
\hline & & missg. & low & med. & high & & missg. & low & med. & high & \\
\hline Low & 14.16 & 23.54 & 11.46 & 6.51 & 6.23 & 13.30 & 27.40 & 12.18 & 6.99 & 6.95 & 8.61 \\
\hline Medium & 66.73 & 66.59 & 81.02 & 72.35 & 31.76 & 68.34 & 65.01 & 78.29 & 68.07 & 30.16 & 68.09 \\
\hline High & 19.10 & 9.87 & 7.53 & 21.14 & 62.01 & 18.36 & 7.60 & 9.53 & 24.94 & 62.89 & 23.30 \\
\hline Total & 100.0 & 100.0 & 100.0 & 100.0 & 100.0 & 100.0 & 100.0 & 100.0 & 100.0 & 100.0 & 100.0 \\
\hline $\mathrm{N}$ obs. & 9,809 & 446 & 3,893 & 29,352 & 4,449 & 2,233 & 803 & 9,069 & 33,469 & 2,374 & 47,948 \\
\hline
\end{tabular}

Panel B Transition Matrices for Second Generation Immigrants (in column percent)

\begin{tabular}{l|rrrr|rrrrrr|r}
\hline $\begin{array}{l}\text { Child } \\
\text { education }\end{array}$ & $\begin{array}{c}\text { No } \\
\text { Father }\end{array}$ & \multicolumn{3}{|c|}{ Father's Education } & \multicolumn{2}{c}{ No } & \multicolumn{4}{c|}{ Mother's Education } & Total \\
& & missg. & low & med. & high & Mother & missg. & low & med. & high & \\
\hline Low & 20.25 & 27.63 & 17.98 & 10.76 & 9.95 & 20.78 & 27.99 & 18.36 & 10.82 & 10.25 & 14.51 \\
Medium & 53.32 & 58.45 & 66.54 & 60.20 & 24.30 & 58.43 & 55.84 & 66.69 & 55.2 & 26.42 & 55.34 \\
High & 26.43 & 13.92 & 15.47 & 29.04 & 65.76 & 20.78 & 16.17 & 14.95 & 33.98 & 63.33 & 30.15 \\
\hline Total & 100.0 & 100.0 & 100.0 & 100.0 & 100.0 & 100.0 & 100.0 & 100.0 & 100.0 & 100.0 & 100.0 \\
\hline N obs. & 2,183 & 503 & 3,787 & 5,912 & 2,202 & 510 & 668 & 5,104 & 6,265 & 2,040 & 14,587 \\
\hline
\end{tabular}


Panel C Probability of High Child Education by Level of Parental Education and for Various Subsamples (all probabilities in percent)

\begin{tabular}{|c|c|c|c|c|c|c|c|c|c|}
\hline \multirow[t]{3}{*}{ Subsample } & \multirow{3}{*}{$\begin{array}{l}\mathrm{N} \\
(1) \\
\end{array}$} & \multicolumn{4}{|c|}{ Conditional on Father's Education } & \multicolumn{4}{|c|}{ Conditional on Mother's Education } \\
\hline & & F low & F high & Diff. $(4)=$ & Ratio $(5)=$ & M low & M high & Diff. $(8)=$ & Ratio (9) $=$ \\
\hline & & $(2)$ & $(3)$ & $(3)-(2)$ & $(3) /(2)$ & $(6)$ & $(7)$ & $(6)-(7)$ & $(7) /(6)$ \\
\hline All Natives & 47,948 & 7.5 & 62.0 & 54.5 & 8.2 & 9.5 & 62.9 & 53.4 & 6.6 \\
\hline Male Natives & 24,775 & 5.0 & 57.3 & 52.3 & 11.4 & 6.9 & 58.8 & 51.8 & 8.5 \\
\hline Female Natives & $\underline{23}, \underline{17} \underline{3}$ & 10.2 & $\underline{67} . \underline{0}$ & $\underline{56} . \underline{8}$ & 6.6 & 12.3 & $\underline{67} . \underline{2}$ & $\underline{54} . \underline{9}$ & 5.5 \\
\hline$\overline{\mathrm{All}} \overline{\mathrm{Second}}$ Generation Immigrants $(\overline{\mathrm{SGI}})$ & $\overline{14} \overline{5} \overline{5} 8 \overline{7}$ & $\overline{15} . \overline{5}$ & $\overline{65} . \overline{8}$ & $\overline{50 . \overline{3}}$ & $4 . \overline{3}$ & $\overline{15} . \overline{0}$ & $\overline{63} . \overline{3}$ & $\overline{48} . \overline{4}$ & $\overline{4.2}$ \\
\hline Male SGI & 7,568 & 12.1 & 60.1 & 48.0 & 5.0 & 11.4 & 56.7 & 45.3 & 5.0 \\
\hline Female SGI $-----\ldots$ & - 7, $\underline{0} 19$ & 19.4 & $\underline{71} . \underline{4}$ & $\underline{52} .0$ & 3.7 & $18 . \underline{9}$ & 70.4 & $\underline{51.5}$ & 3.7 \\
\hline Natives: German language municipalities & $\overline{3} 7, \overline{7} 6 \overline{3}$ & $5 . \overline{3}$ & $\overline{57.1}$ & $\overline{5} 1 . \overline{8}$ & $\overline{10} . \overline{8}$ & 7.1 & $\overline{59} . \overline{3}$ & $\overline{52} . \overline{2}$ & $\overline{8.4}$ \\
\hline Natives: French language municipalities & 8,602 & 14.8 & 75.6 & 60.8 & 5.1 & 17.5 & 68.5 & 50.9 & 3.9 \\
\hline Natives: Italian language municipalities & 1,329 & 26.9 & 79.2 & 52.3 & 2.9 & 25.5 & 76.9 & 51.3 & 3.0 \\
\hline Natives: Rhaeto-Romanic lang. municipalities & $---25 \underline{4}$ & $\underline{11} . \underline{8}$ & $\underline{66} .7$ & $\underline{54} . \underline{9}$ & 5.7 & 5.7 & 66.7 & $\underline{61} . \underline{0}$ & 11.7 \\
\hline Natives in single parent household & $\overline{2}, \overline{239} \overline{/ 9,809}$ & $-\overline{2} . \overline{9}$ & $\overline{49} . \overline{6}$ & $\overline{46} . \overline{7}$ & $\overline{17.1}$ & $7 . \overline{6}$ & $\overline{52} . \overline{6}$ & $\overline{45} . \overline{0}$ & $\overline{7.0}$ \\
\hline Natives in double parent household & $--\underline{35,906}$ & 7.8 & $\underline{62} .8$ & $\underline{55} . \underline{0}$ & 8.0 & $\underline{10.1}$ & $\underline{66} \cdot \underline{0}$ & $\underline{55} . \underline{9}$ & 6.5 \\
\hline SGI from Africa & 681 & $\overline{35} . \overline{6}$ & $\overline{74} . \overline{6}$ & $\overline{39} . \overline{0}$ & $2 . \overline{1}$ & 28.0 & $\overline{72} . \overline{6}$ & $\overline{44} . \overline{6}$ & $\overline{2.6}$ \\
\hline SGI from Northern and Eastern Europe & 1,046 & 21.6 & 65.5 & 43.9 & 3.0 & 18.9 & 61.5 & 42.5 & 3.3 \\
\hline SGI from Southern Europe & 6,545 & 15.9 & 56.4 & 40.6 & 3.6 & 14.9 & 57.0 & 42.1 & 3.8 \\
\hline SGI from Western Europe & 3,637 & 15.1 & 67.9 & 52.8 & 4.5 & 15.2 & 64.0 & 48.8 & 4.2 \\
\hline SGI from Western Asia & 979 & 8.2 & 55.9 & 47.7 & 6.8 & 7.6 & 62.3 & 54.7 & 8.2 \\
\hline SGI from Latin America & 461 & 18.6 & 70.2 & 51.6 & 3.8 & 22.0 & 59.1 & 37.1 & 2.7 \\
\hline SGI from North America & 238 & 33.3 & 60.4 & 27.1 & 1.8 & 42.9 & 71.4 & 28.6 & 1.7 \\
\hline SGI from Asia and Oceania $-\ldots$ & $-\underline{7} 16$ & $\underline{23} . \underline{6}$ & $\underline{74} . \underline{9}$ & $\underline{51} . \underline{2}$ & 3.2 & $\underline{24} . \underline{0}$ & $\underline{68} . \underline{3}$ & $\underline{44} . \underline{3}$ & 2.9 \\
\hline SGI: $\geq 1$ parent Swiss national since birth & $6, \overline{5} 8 \overline{7}$ & $\overline{18.5}$ & $\overline{68.1}$ & $\overline{49} . \overline{6}$ & $3 . \overline{7}$ & $\overline{17} . \overline{2}$ & $\overline{65} . \overline{7}$ & $\overline{48} . \overline{5}$ & $\overline{3.8}$ \\
\hline SGI: $\geq 1$ parent Swiss national since $\geq 5$ years & 1,993 & 20.3 & 67.9 & 47.6 & 3.4 & 17.8 & 58.5 & 40.7 & 3.3 \\
\hline SGI: $\geq 1$ parent Swiss national since $<5$ years & 648 & 19.8 & 59.2 & 39.4 & 3.0 & 18.9 & 59.4 & 40.5 & 3.2 \\
\hline SGI: No parent Swiss national & 5,359 & 13.9 & 57.1 & 43.2 & 4.1 & 13.3 & 63.8 & 50.5 & 4.8 \\
\hline
\end{tabular}


Panel D Probability of High Child Education by Level of Parental Education and for Various Subsamples (all probabilities in percent)

\begin{tabular}{|c|c|c|c|c|c|c|c|}
\hline \multirow[t]{2}{*}{ Subsample } & \multirow{2}{*}{$\begin{array}{l}\mathrm{N} \\
\text { (1) }\end{array}$} & \multicolumn{3}{|c|}{ Condition. on Father's Educ. } & \multicolumn{3}{|c|}{ Condition. on Mother's Educ. } \\
\hline & & $\begin{array}{c}\text { F low } \\
(2)\end{array}$ & $\begin{array}{l}\text { F high } \\
\text { (3) }\end{array}$ & $\begin{array}{l}\text { Diff. (4) } \\
=(3)-(2)\end{array}$ & $\begin{array}{c}\text { M low } \\
(5)\end{array}$ & $\begin{array}{l}\text { M high } \\
(6)\end{array}$ & $\begin{array}{l}\text { Diff. (7) } \\
=(6)-(5) \\
\end{array}$ \\
\hline \multicolumn{8}{|l|}{ Baseline Effects } \\
\hline All Natives & 47,948 & 7.5 & 62.0 & 54.5 & 9.5 & 62.9 & 53.4 \\
\hline All Second Gen. Immigrants & 14,587 & 15.5 & 65.8 & 50.3 & 15.0 & 63.3 & 48.4 \\
\hline \multicolumn{8}{|l|}{ Cost Effects - Natives } \\
\hline Region densely populated & 13,726 & 9.0 & 66.4 & 57.4 & 11.0 & 69.2 & 58.2 \\
\hline Region sparsely populated & 34,222 & 7.3 & 58.9 & 51.7 & 9.1 & 57.7 & 48.5 \\
\hline High youth unemployment & 20,526 & 11.7 & 67.2 & 55.5 & 14.1 & 65.6 & 51.5 \\
\hline Low youth unemployment & 27,422 & 5.2 & $\underline{56.3}$ & $\underline{51.0}$ & 6.6 & $\underline{58.7}$ & $\underline{52} .1$ \\
\hline \multicolumn{8}{|l|}{ Sibling Effects - Natives } \\
\hline No siblings & 3,363 & 11.6 & 64.1 & 52.6 & 11.9 & 60.2 & 48.4 \\
\hline One sibling & 21,821 & 8.1 & 63.3 & 55.2 & 10.2 & 63.7 & 53.5 \\
\hline Two siblings & 14,908 & 7.5 & 61.1 & 53.7 & 9.3 & 63.6 & 54.3 \\
\hline More than two siblings & 7,856 & 6.1 & 60.5 & $\underline{54} . \underline{4}$ & 7.7 & $\underline{60.6}$ & $\underline{52} . \underline{9}$ \\
\hline \multicolumn{8}{|c|}{ Cost Effects - Second Generation Immigrants (SGI) } \\
\hline Region densely populated & 4,351 & 21.7 & 71.0 & 49.3 & 19.9 & 67.7 & 47.8 \\
\hline Region sparsely populated & 10,236 & 12.7 & 62.9 & 50.2 & 13.0 & 60.9 & 47.9 \\
\hline High youth unemployment & 5,106 & 28.3 & 74.8 & 46.5 & 27.4 & 71.7 & 44.3 \\
\hline Low youth unemployment & 9,481 & 9.6 & 59.1 & $\underline{49} . \underline{5}$ & 9.6 & $\underline{56.8}$ & 47.2 \\
\hline \multicolumn{8}{|c|}{ Sibling Effects - Second Generation Immigrants (SGI) } \\
\hline No siblings & 1,238 & 24.8 & 71.4 & 46.7 & 20.9 & 58.5 & 37.6 \\
\hline One sibling & 7,356 & 17.4 & 65.8 & 48.4 & 17.2 & 62.7 & 45.5 \\
\hline Two siblings & 4,152 & 12.9 & 66.1 & 53.2 & 12.3 & 64.3 & 52.0 \\
\hline More than two siblings & 1,841 & 10.8 & 62.5 & $\underline{51.8}$ & 9.9 & 68.4 & 58.6 \\
\hline \multicolumn{8}{|c|}{ Ethnic Effects - Second Generation Immigrants } \\
\hline $\begin{array}{l}\text { Many highly educated } \\
\text { compatriots }\end{array}$ & 4,043 & 26.9 & 69.1 & 42.2 & 23.5 & 66.2 & 42.7 \\
\hline $\begin{array}{l}\text { Few highly educated } \\
\text { compatriots }\end{array}$ & 10,544 & 12.9 & 64.2 & 51.3 & 13.1 & 62.1 & 48.9 \\
\hline From high illiteracy country & 2,668 & 15.0 & 71.3 & 56.3 & 15.5 & 69.6 & 54.1 \\
\hline From low illiteracy country & 11,919 & 15.6 & 64.1 & 48.4 & 14.8 & 61.8 & 47.0 \\
\hline
\end{tabular}

Note: Individuals were grouped based on whether their realization of the sorting variable was above or below the sample mean regarding population density, cantonal youth unemployment, number highly educated compatriots, and home country illiteracy. The sample means were determined separately for natives and second generation immigrants.

Source: $\quad$ Own calculations using Swiss Census 2000. 
Table 4(A) Ordered Probit Estimation of Determinants of Child Educational Attainment Natives Only - Marginal Effects

\begin{tabular}{|c|c|c|c|}
\hline & \multicolumn{3}{|c|}{ Prob. of Reaching Education } \\
\hline & Low & Middle & High \\
\hline & $\begin{array}{l}\text { Marg. Effect } \\
\text { (Std. Error) }\end{array}$ & $\begin{array}{l}\text { Marg. Effect } \\
\text { (Std. Error) }\end{array}$ & $\begin{array}{l}\text { Marg. Effec } \\
\text { (Std. Error) }\end{array}$ \\
\hline Average predicted probability & 0.069 & 0.717 & 0.213 \\
\hline Parental Education & & & \\
\hline Father Low $(0 / 1)$ & $\begin{array}{l}0.036^{* *} \\
(0.004)\end{array}$ & $\begin{array}{l}0.027 * * \\
(0.002)\end{array}$ & $\begin{array}{l}-0.062 * * \\
(0.006)\end{array}$ \\
\hline Father High $(0 / 1)$ & $\begin{array}{l}-0.053^{* *} \\
(0.002)\end{array}$ & $\begin{array}{l}-0.133^{* *} \\
(0.008)\end{array}$ & $\begin{array}{l}0.186^{* *} \\
(0.009)\end{array}$ \\
\hline Mother Low (0/1) & $\begin{array}{l}0.041^{* *} \\
(0.003)\end{array}$ & $\begin{array}{l}0.033^{* *} \\
(0.002)\end{array}$ & $\begin{array}{l}-0.074 * * \\
(0.004)\end{array}$ \\
\hline Mother High $(0 / 1)$ & $\begin{array}{l}-0.048 * * \\
(0.002)\end{array}$ & $\begin{array}{l}-0.125^{* *} \\
(0.009)\end{array}$ & $\begin{array}{l}0.173^{* *} \\
(0.011)\end{array}$ \\
\hline Father Missing $(0 / 1)$ & $\begin{array}{r}-0.010 \\
(0.014)\end{array}$ & $\begin{array}{r}-0.013 \\
(0.020)\end{array}$ & $\begin{array}{r}0.023 \\
(0.034)\end{array}$ \\
\hline Mother Missing $(0 / 1)$ & $\begin{array}{l}-0.050^{* *} \\
(0.005)\end{array}$ & $\begin{array}{l}-0.136^{* *} \\
(0.028)\end{array}$ & $\begin{array}{l}0.186^{* *} \\
(0.033)\end{array}$ \\
\hline Father No Response $(0 / 1)$ & $\begin{array}{l}0.034^{* *} \\
(0.011)\end{array}$ & $\begin{array}{l}0.024^{* *} \\
(0.004)\end{array}$ & $\begin{array}{l}-0.058^{* *} \\
(0.015)\end{array}$ \\
\hline Mother No Response $(0 / 1)$ & $\begin{array}{l}0.118^{* *} \\
(0.012)\end{array}$ & $\begin{array}{l}0.015^{* *} \\
(0.005)\end{array}$ & $\begin{array}{l}-0.133^{* *} \\
(0.007)\end{array}$ \\
\hline Household Characteristics & & & \\
\hline Father Occ. Position: No training $(0 / 1)$ & $\begin{array}{r}-0.006 \\
(0.011)\end{array}$ & $\begin{array}{r}-0.008 \\
(0.016)\end{array}$ & $\begin{array}{r}0.014 \\
(0.027)\end{array}$ \\
\hline Father Occ. Position: Low qualified blue collar $(0 / 1)$ & $\begin{array}{r}0.010 \\
(0.012)\end{array}$ & $\begin{array}{r}0.010 \\
(0.011)\end{array}$ & $\begin{array}{r}-0.020 \\
(0.024)\end{array}$ \\
\hline Father Occ. Position: Low qualified white collar $(0 / 1)$ & $\begin{array}{r}-0.001 \\
(0.011)\end{array}$ & $\begin{array}{r}-0.001 \\
\text { (n.a.) }\end{array}$ & $\begin{array}{c}0.002+ \\
(0.025)\end{array}$ \\
\hline Father Occ. Position: Intermediate level occup. (0/1) & $\begin{array}{l}-0.021 * \\
(0.009)\end{array}$ & $\begin{array}{l}-0.030+ \\
(0.017)\end{array}$ & $\begin{array}{r}0.051 \\
(0.026)\end{array}$ \\
\hline Father Occ. Position: Other self employed $(0 / 1)$ & $\begin{array}{r}-0.01 \\
(0.010)\end{array}$ & $\begin{array}{r}-0.013 \\
(0.015)\end{array}$ & $\begin{array}{l}0.023^{* *} \\
(0.025)\end{array}$ \\
\hline Father Occ. Position: Academic / upper mngmt. (0/1) & $\begin{array}{l}-0.034^{* *} \\
(0.008)\end{array}$ & $\begin{array}{l}-0.064 * * \\
(0.021)\end{array}$ & $\begin{array}{l}0.098^{* *} \\
(0.029)\end{array}$ \\
\hline Father Occ. Position: Qualified self employed (0/1) & $\begin{array}{l}-0.035^{* *} \\
(0.007)\end{array}$ & $\begin{array}{l}-0.074 * * \\
(0.026)\end{array}$ & $\begin{array}{c}0.11^{* *} \\
(0.033)\end{array}$ \\
\hline Father Occ. Position: Top management $(0 / 1)$ & $\begin{array}{l}-0.034^{* *} \\
(0.007)\end{array}$ & $\begin{array}{l}-0.068 * * \\
(0.024)\end{array}$ & $\begin{array}{r}0.102 \\
(0.031)\end{array}$ \\
\hline Father Occ. Position: Not employed $(0 / 1)$ & $\begin{array}{r}0.015 \\
(0.014)\end{array}$ & $\begin{array}{r}0.014 \\
(0.011)\end{array}$ & $\begin{array}{r}-0.029 \\
(0.025)\end{array}$ \\
\hline Father Occ. Position: Other $(0 / 1)$ & $\begin{array}{l}-0.007 \\
(0.011)\end{array}$ & $\begin{array}{l}-0.009 \\
(0.015)\end{array}$ & $\begin{array}{c}0.015+ \\
(0.025)\end{array}$ \\
\hline
\end{tabular}


Mother Occ. Position: No training (0/1)

Mother Occ. Position: Low qualified blue collar (0/1)

Mother Occ. Position: Low qualified white collar (0/1)

Mother Occ. Position: Intermediate level occup. (0/1)

Mother Occ. Position: Other self employed (0/1)

Mother Occ. Position: Academic / upper mngmt.(0/1)

Mother Occ. Position: Qualified self employed (0/1)

Mother Occ. Position: Top management (0/1)

Mother Occ. Position: Not employed (0/1)

Mother Occ. Position: Other (0/1)

Father Age

Mother Age

One Sibling $(0 / 1)$

Two Siblings (0/1)

Three or more Siblings (0/1)

Individual Characteristics

Female (0/1)

Religion: Jewish (0/1)

Religion: Islamic (0/1)

Religion: Other or no denomination $(0 / 1)$

Religion: No response (0/1)

\section{Regional Characteristics}

Population Density

Cantonal Youth Unemployment Rate 1999

Region 2 (Mittelland) (0/1)

$\begin{array}{ccc}-0.011+ & -0.015 & 0.026 \\ (0.006) & (0.009) & (0.015) \\ -0.006 & -0.008 & 0.014 * * \\ (0.007) & (0.01) & (0.018) \\ -0.022 * * & -0.031 * * & 0.053 * * \\ (0.005) & (0.009) & (0.014) \\ -0.046 * * & -0.104 * * & 0.150 * * \\ (0.004) & (0.013) & (0.017) \\ -0.025 * * & -0.042 * * & 0.067 * * \\ (0.005) & (0.011) & (0.016) \\ -0.039 * * & -0.089 * * & 0.128 * * \\ (0.004) & (0.017) & (0.022) \\ -0.037 * * & -0.081 * & 0.118 * * \\ (0.008) & (0.032) & (0.040) \\ -0.031 * * & -0.063 * * & 0.094 * * \\ (0.008) & (0.024) & (0.032) \\ -0.018 * * & -0.025 * * & 0.042 * * \\ (0.005) & (0.008) & (0.014) \\ -0.017 * * & -0.024 * * & 0.041 * * \\ (0.005) & (0.009) & (0.014) \\ -0.001 * * & -0.001 * * & 0.001 * * \\ (0.000) & (0.000) & (0.000) \\ -0.002 * * & -0.002 * * & 0.004 \\ (0.000) & (0.000) & (0.000) \\ -0.001 & -0.001 & 0.001 \\ (0.003) & (0.004) & (0.007) \\ 0.002 & 0.003 & -0.005 \\ (0.003) & (0.004) & (0.007) \\ 0.005 & 0.005 & -0.010 \\ (0.004) & (0.004) & (0.007) \\ & & \end{array}$

$\begin{array}{ccc}-0.020 * * & -0.023 * * & 0.043 \\ (0.001) & (0.002) & (0.003) \\ 0.017 & 0.015 & -0.032 * * \\ (0.025) & (0.017) & (0.042) \\ 0.092 * * & 0.022 * * & -0.115 * \\ (0.028) & (0.008) & (0.020) \\ 0.004 & 0.005 & -0.009 * * \\ (0.003) & (0.003) & (0.006) \\ 0.104 * * & 0.020 * * & -0.124 \\ (0.013) & (0.005) & (0.008)\end{array}$

$\begin{array}{ccc}-0.084 & -0.099 & 0.182 * * \\ (0.057) & (0.068) & (0.125) \\ -0.011 * * & -0.013 * * & 0.025 * * \\ (0.002) & (0.002) & (0.004) \\ 0.018 * * & 0.019 * * & -0.038 * * \\ (0.004) & (0.003) & (0.007)\end{array}$


Region 3 (Northwestern Switzerland) (0/1)

\begin{tabular}{ccc}
$0.036^{* *}$ & $0.028^{* *}$ & $-0.065 * *$ \\
$(0.005)$ & $(0.002)$ & $(0.007)$ \\
$0.046^{* *}$ & $0.033^{* *}$ & $-0.079 * *$ \\
$(0.005)$ & $(0.002)$ & $(0.007)$ \\
$0.023^{* *}$ & $0.022^{* *}$ & $-0.045 * *$ \\
$(0.005)$ & $(0.004)$ & $(0.009)$ \\
$0.016^{* *}$ & $0.016^{* *}$ & $-0.032 * *$ \\
$(0.005)$ & $(0.004)$ & $(0.010)$ \\
$-0.040^{* *}$ & $-0.093 * *$ & $0.133 * *$ \\
$(0.003)$ & $(0.011)$ & $(0.014)$ \\
\hline
\end{tabular}

Note: $* *, *$, and + represent statistical significance of the marginal effect at the 1,5 , and 10 percent level, respectively.

Source: Own calculations based on census 2000. 
Table 4(B) Ordered Probit Estimation of Determinants of Child Educational Attainment Second Generation Immigrants Only - Marginal Effects

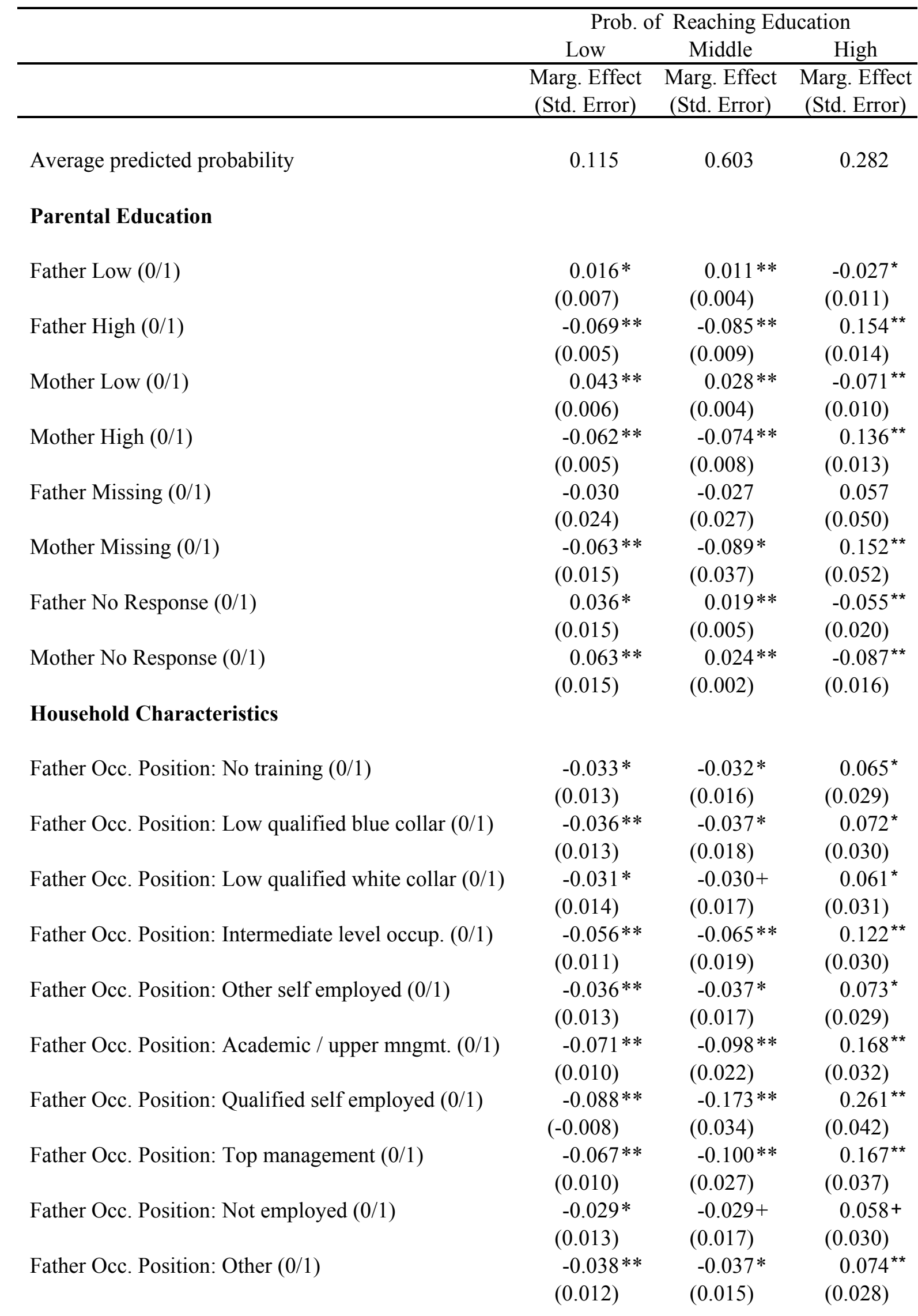


Mother Occ. Position: No training (0/1)

$\begin{array}{ccc}-0.012 & -0.009 & 0.021 \\ (0.011) & (0.009) & (0.020) \\ -0.002 & -0.002 & 0.004 \\ (0.02) & (0.015) & (0.035) \\ -0.018+ & -0.015 & 0.033+ \\ (0.010) & (0.010) & (0.020) \\ -0.045 * * & -0.050 * * & 0.096^{* *} \\ (0.009) & (0.014) & (0.023) \\ -0.007 & -0.005 & 0.012 \\ (0.013) & (0.011) & (0.024) \\ -0.058 * * & -0.078 * * & 0.135^{* *} \\ (0.010) & (0.022) & (0.031) \\ -0.074 * * & -0.125 * * & 0.199 * \\ (0.014) & (0.048) & (0.062) \\ -0.023 & -0.021 & 0.044 \\ (0.020) & (0.023) & (0.043) \\ -0.010 & -0.008 & 0.017 \\ (0.010) & (0.008) & (0.019) \\ -0.006 & -0.005 & 0.011 \\ (0.010) & (0.008) & (0.019) \\ -0.001 & 0.000 & 0.001 \\ (0.000) & (0.000) & (0.001) \\ -0.003 * * & -0.002 * * & 0.005^{* *} \\ (0.000) & (0.000) & (0.001) \\ 0.000 & 0.000 & 0.000 \\ (0.007) & (0.005) & (0.012) \\ 0.013 & 0.009+ & -0.021+ \\ (0.008) & (0.005) & (0.013) \\ 0.036 * * & 0.020 * * & -0.056^{* *} \\ (0.010) & (0.004) & (0.014)\end{array}$

Individual Characteristics

Female (0/1)

$\begin{array}{ccc}-0.036^{* *} & -0.027^{* *} & 0.063^{* *} \\ (0.004) & (0.003) & (0.007) \\ 0.030 & 0.016+ & -0.046 \\ (0.027) & (0.010) & (0.036) \\ 0.025^{*} & 0.014^{* *} & -0.039^{*} \\ (0.011) & (0.005) & (0.017) \\ -0.010+ & -0.008 & 0.018^{+} \\ (0.006) & (0.005) & (0.011) \\ 0.117^{* *} & 0.018^{* *} & -0.136^{* *} \\ (0.023) & (0.006) & (0.018)\end{array}$

\section{Regional Characteristics}

Population Density

$\begin{array}{ccc}0.037 & 0.027 & -0.064 \\ (0.092) & (0.068) & (0.160) \\ -0.015^{* *} & -0.011^{* *} & 0.027^{* *} \\ (0.005) & (0.004) & (0.009) \\ 0.045^{* *} & 0.024 * * & -0.069^{* *} \\ (0.011) & (0.004) & (0.015)\end{array}$




\begin{tabular}{|c|c|c|c|}
\hline Region 3 (Northwestern Switzerland) (0/1) & $\begin{array}{l}0.065^{* *} \\
(0.013)\end{array}$ & $\begin{array}{l}0.029 * * \\
(0.003)\end{array}$ & $\begin{array}{l}-0.094^{* *} \\
(0.016)\end{array}$ \\
\hline Region 4 (Zurich) $(0 / 1)$ & $0.064 * *$ & $0.03 * *$ & $-0.094^{* *}$ \\
\hline & $(0.012)$ & $(0.003)$ & $(0.014)$ \\
\hline Region 5 (Eastern Switzerland) (0/1) & $0.062 * *$ & $0.028 * *$ & $-0.090^{* *}$ \\
\hline & $(0.015)$ & $(0.003)$ & $(0.018)$ \\
\hline Region 6 (Central Switzerland) (0/1) & $0.055 * *$ & $0.024 * *$ & $-0.079^{\star *}$ \\
\hline & $(0.018)$ & $(0.003)$ & $(0.021)$ \\
\hline Region 7 (Ticino) $(0 / 1)$ & $-0.046 * *$ & $-0.052 * *$ & $0.098^{* *}$ \\
\hline & $(0.007)$ & $(0.011)$ & $(0.018)$ \\
\hline Immigrant Characteristics & & & \\
\hline At least one parent Swiss since at least 5 years. $(0 / 1)$ & -0.007 & -0.005 & 0.012 \\
\hline & $(0.007)$ & $(0.006)$ & $(0.012)$ \\
\hline At least one parent Swiss since up to 5 years. $(0 / 1)$ & $-0.022 *$ & $-0.021 *$ & $0.043^{*}$ \\
\hline & $(0.009)$ & $(0.01)$ & $(0.018)$ \\
\hline Both Parents Not Swiss Citizens (0/1) & 0.000 & 0.000 & 0.000 \\
\hline & $(0.006)$ & $(0.004)$ & $(0.01)$ \\
\hline Country of origin: Africa $(0 / 1)$ & -0.010 & -0.008 & 0.018 \\
\hline & $(0.016)$ & $(0.014)$ & $(0.029)$ \\
\hline Country of origin: Europe $(0 / 1)$ & $0.030 * *$ & $0.017 * *$ & $-0.046^{* *}$ \\
\hline & $(0.011)$ & $(0.004)$ & $(0.015)$ \\
\hline Country of origin: Southern Europe (0/1) & 0.009 & 0.006 & -0.015 \\
\hline & $(0.007)$ & $(0.005)$ & $(0.011)$ \\
\hline Country of origin: Western Asia (0/1) & $0.040 * *$ & $0.020 * *$ & $-0.060^{* *}$ \\
\hline & $(0.015)$ & $(0.005)$ & $(0.020)$ \\
\hline Country of origin: Latin America $(0 / 1)$ & $0.024+$ & $0.014 *$ & $-0.039+$ \\
\hline & $(0.014)$ & $(0.006)$ & $(0.021)$ \\
\hline Country of origin: North America (0/1) & 0.016 & 0.010 & -0.026 \\
\hline & $(0.018)$ & $(0.009)$ & $(0.027)$ \\
\hline Country of origin: Asia and Oceania $(0 / 1)$ & 0.001 & 0.000 & -0.001 \\
\hline & $(0.012)$ & $(0.009)$ & $(0.020)$ \\
\hline Country of origin: Other $(0 / 1)$ & 0.030 & $0.016 *$ & $-0.046+$ \\
\hline & $(0.019)$ & $(0.007)$ & $(0.027)$ \\
\hline Main Language not equals cantonal language $(0 / 1)$ & $0.015+$ & $0.009 *$ & $-0.024+$ \\
\hline & $(0.008)$ & $(0.005)$ & $(0.013)$ \\
\hline Home country illiteracy rate & 0.000 & 0.000 & 0.000 \\
\hline & $(0.000)$ & $(0.000)$ & $(0.001)$ \\
\hline Home country illteracy rate missing $(0 / 1)$ & $0.028 * *$ & $0.016 * *$ & $-0.045^{\star *}$ \\
\hline & $(0.009)$ & $(0.004)$ & $(0.013)$ \\
\hline Number highly educated co-ethnics by Region & $0.002 * *$ & $0.002 * *$ & $-0.004^{* *}$ \\
\hline & $(0.001)$ & $(0.001)$ & $(0.002)$ \\
\hline
\end{tabular}

Note: $* *, *$, and + represent statistical significance of the marginal effect at the 1,5 , and 10 percent level, respectively.

Source: Own calculations based on census 2000. 
Table 4(C) Simulation Results of the Two Main Models

\begin{tabular}{lcccc}
\hline & \multicolumn{2}{c}{ Estimation with covariates } \\
Natives & $\begin{array}{c}\text { Estimation without covariates } \\
\text { Seneration } \\
\text { Immigrants }\end{array}$ & Natives & $\begin{array}{c}\text { Second } \\
\text { Generation } \\
\text { Immigrants }\end{array}$ \\
\hline (1) Pr (high | parents low) & 10.33 & 19.84 & 9.07 & 16.60 \\
(2) $\operatorname{Pr}$ (high | parents middle) & 21.61 & 28.32 & 24.02 & 31.92 \\
(3) $\operatorname{Pr}$ (high | parents high) & 58.86 & 56.86 & 74.89 & 71.24 \\
\hline Difference (3) - (1) & 48.54 & 37.02 & 65.82 & 54.64 \\
Ratio (3) / (1) & 5.70 & 2.87 & 8.26 & 4.29 \\
\hline
\end{tabular}

Source: Own calculations using Swiss Census 2000. 
Table 5(A) Simulation Results of Interacted Models - Cost Factors

\begin{tabular}{|c|c|c|c|c|c|c|c|c|}
\hline & \multicolumn{4}{|c|}{ Natives } & \multicolumn{4}{|c|}{ Second Generation Immig. } \\
\hline & \multicolumn{2}{|c|}{$\begin{array}{l}\text { Population } \\
\text { Density }\end{array}$} & \multicolumn{2}{|c|}{$\begin{array}{c}\text { Cantonal } \\
\text { Unemployment }\end{array}$} & \multicolumn{2}{|c|}{$\begin{array}{l}\text { Population } \\
\text { Density }\end{array}$} & \multicolumn{2}{|c|}{ Cantonal } \\
\hline \multirow[t]{2}{*}{$\begin{array}{l}\text { Joint significance of } 8 \text { interaction } \\
\text { coefficients, } \mathrm{chi}^{2} \text { ( } \mathrm{p} \text { value): }\end{array}$} & \multicolumn{2}{|c|}{$\begin{array}{r}83.79 \\
(0.000) \\
\end{array}$} & \multicolumn{2}{|c|}{$\begin{array}{c}41.18 \\
(0.000)\end{array}$} & \multicolumn{2}{|c|}{$\begin{array}{c}8.76 \\
(0.363) \\
\end{array}$} & \multicolumn{2}{|c|}{$\begin{array}{c}10.37 \\
(0.240)\end{array}$} \\
\hline & $\begin{array}{l}\text { Dens. } \\
\text { high }\end{array}$ & $\begin{array}{l}\text { Dens. } \\
\text { low }\end{array}$ & $\begin{array}{l}\text { Unem. } \\
\text { high }\end{array}$ & $\begin{array}{l}\text { Unem. } \\
\text { low }\end{array}$ & $\begin{array}{l}\text { Dens. } \\
\text { high }\end{array}$ & $\begin{array}{l}\text { Dens. } \\
\text { low }\end{array}$ & $\begin{array}{l}\text { Unem. } \\
\text { high }\end{array}$ & $\begin{array}{l}\text { Unem. } \\
\text { low }\end{array}$ \\
\hline (1) $\operatorname{Pr}$ (high $\mid$ parents low) & 7.63 & 11.32 & 9.76 & 10.17 & 19.97 & 19.69 & 19.85 & 18.42 \\
\hline (2) $\operatorname{Pr}$ (high $\mid$ parents middle) & 22.34 & 21.28 & 23.98 & 19.31 & 27.90 & 28.62 & 29.44 & 24.50 \\
\hline (3) $\operatorname{Pr}$ (high | parents high) & 61.30 & 56.16 & 61.79 & 56.43 & 56.99 & 56.67 & 57.43 & 56.22 \\
\hline Difference (3) - (1) & 53.66 & 44.83 & 52.03 & 46.26 & 37.02 & 36.97 & 37.58 & 37.80 \\
\hline Ratio (3) / (1) & 8.03 & 4.96 & 6.33 & 5.55 & 2.85 & 2.88 & 2.89 & 3.05 \\
\hline
\end{tabular}

Table 5(B) Simulation Results of Interacted Models - Sibling Effects

\begin{tabular}{lrrrr}
\hline & \multicolumn{5}{c}{ Sibling Effects - Natives } \\
\hline $\begin{array}{l}\text { Joint significance of 24 interaction coefficients, } \\
\text { chi }^{2} \text { (p value): }\end{array}$ & \multicolumn{5}{c}{$\begin{array}{c}\text { 27.65 } \\
\text { (0.275) }\end{array}$} \\
\hline & no siblings & 1 sibling & 2 siblings & $>2$ siblings \\
\hline (1) $\operatorname{Pr}$ (high | parents low) & 8.00 & 10.41 & 9.84 & 10.76 \\
(2) $\operatorname{Pr}$ (high | parents middle) & 22.62 & 22.13 & 21.33 & 20.56 \\
(3) $\operatorname{Pr}($ high | parents high) & 56.86 & 61.41 & 57.47 & 56.03 \\
\hline Difference (3) - (1) & 48.87 & 51.00 & 47.63 & 45.27 \\
Ratio (3) / (1) & 7.11 & 5.90 & 5.84 & 5.21 \\
\hline
\end{tabular}

\begin{tabular}{lrrrr}
\hline & \multicolumn{3}{c}{ Sibling Effects - Second Generation Immigrants } \\
\hline $\begin{array}{l}\text { Joint significance of 24 interaction coefficients, } \\
\text { chi }^{2} \text { (p value): }\end{array}$ & \multicolumn{5}{c}{$\begin{array}{c}37.21 \\
(0.042)\end{array}$} \\
\hline & no siblings & 1 sibling & 2 siblings & $>2$ siblings \\
\hline (1) $\operatorname{Pr}$ (high | parents low) & 20.82 & 21.26 & 18.92 & 15.21 \\
(2) $\operatorname{Pr}($ high | parents middle) & 30.34 & 28.69 & 28.36 & 24.49 \\
(3) $\operatorname{Pr}($ high | parents high) & 59.61 & 56.69 & 55.50 & 59.63 \\
\hline Difference (3) - (1) & 38.78 & 35.43 & 36.57 & 44.42 \\
Ratio (3) / (1) & 2.86 & 2.67 & 2.93 & 3.92 \\
\hline
\end{tabular}


Table 5(C) Simulation Results of Interacted Models - Second Generation Immigrants

\begin{tabular}{|c|c|c|c|c|}
\hline \multirow{3}{*}{$\begin{array}{l}\text { Joint significance of } 8 \text { interaction } \\
\text { coefficients, } \text { chi }^{2} \text { ( } \mathrm{p} \text { value): }\end{array}$} & \multicolumn{2}{|c|}{$\begin{array}{l}\text { \# highly educated } \\
\text { co-ethnics }\end{array}$} & \multicolumn{2}{|c|}{$\begin{array}{l}\text { Home country } \\
\text { illiteracy }\end{array}$} \\
\hline & \multicolumn{2}{|c|}{$\begin{array}{c}12.43 \\
(0.133)\end{array}$} & \multicolumn{2}{|c|}{$\begin{array}{c}15.5 \\
(0.050)\end{array}$} \\
\hline & High & Low & $\begin{array}{l}\text { Illiter. } \\
\text { high }\end{array}$ & $\begin{array}{l}\text { Illiter. } \\
\text { low }\end{array}$ \\
\hline (1) $\operatorname{Pr}$ (high $\mid$ parents low) & 16.34 & 22.01 & 20.10 & 20.13 \\
\hline (2) $\operatorname{Pr}($ high $\mid$ parents middle) & 27.22 & 29.15 & 28.06 & 28.86 \\
\hline (3) $\operatorname{Pr}$ (high $\mid$ parents high) & 55.87 & 57.11 & 58.01 & 56.26 \\
\hline Difference (3) - (1) & 39.53 & 35.10 & 37.91 & 36.13 \\
\hline Ratio (3) / (1) & 3.42 & 2.59 & 2.89 & 2.80 \\
\hline
\end{tabular}

Note: All models are estimated separately for natives and second generation immigrants. The simulations of education cost effects (Panel A) are based on separate estimations for each subsample as are those for ethnic effects in Panel C.

To simulate transition probabilities under high and low population density, the density variables were set to plus one and minus one standard deviations above and below the mean. Since the latter yielded a negative value, zero was used instead. To simulate transition probabilities under high and low unemployment, home country illiteracy rates, and many and few educated co-ethnics the variables were set to one standard deviations above and below the mean. The statistics were calculated separately for the two samples where appropriate.

Source: $\quad$ Own calculations using Swiss Census 2000. 
Table 6 Marginal Effects of a Multinomial Logit Estimation of Child Educational Outcomes for Children of Lowly Educated Parents

\begin{tabular}{|c|c|c|c|c|c|c|}
\hline & \multicolumn{3}{|c|}{$\begin{array}{l}\text { Natives } \\
(\mathrm{N}=4,587)\end{array}$} & \multicolumn{3}{|c|}{$\begin{array}{c}\text { Second Generation } \\
\text { Immigrants }(\mathrm{N}=3,827)\end{array}$} \\
\hline & $\begin{array}{l}\text { Marginal } \\
\text { Effect }\end{array}$ & $\begin{array}{l}\text { ME } \\
\text { Sign. }\end{array}$ & $\begin{array}{l}\text { Coeff. } \\
\text { Sign. }\end{array}$ & $\begin{array}{l}\text { Marginal } \\
\text { Effect }\end{array}$ & $\begin{array}{l}\text { ME } \\
\text { Sign. }\end{array}$ & $\begin{array}{l}\text { Coeff. } \\
\text { Sign. }\end{array}$ \\
\hline 1 Sibling & -1.7 & + & - & -2.9 & + & $*$ \\
\hline 2 Siblings & -1.8 & + & - & -5.8 & $* *$ & $* *$ \\
\hline $3+$ Siblings & -1.7 & + & - & -5.1 & ** & $* *$ \\
\hline Population Density & 41.2 & $*$ & $* *$ & 54.1 & $* *$ & $* *$ \\
\hline Youth Unemployment & -0.1 & - & - & 2.9 & $*$ & + \\
\hline Ethnic Capital & - & - & - & -0.1 & - & - \\
\hline Country of Origin Illiteracy & - & - & - & -0.9 & $* *$ & * \\
\hline Sample Probability of High Education & 6.2 & & & 12.9 & & \\
\hline
\end{tabular}

Note: The column 'Marginal Effect' provides the marginal effect of each covariate on the probability of attaining high educational outcomes for the samples of natives and second generation immigrants with parents of low educational attainment. 'ME Sign.' indicates the level of statistical significance of the marginal effect and 'Coeff. Sign.' provides the level of the joint statistical significance of the covariates' two coefficients in the multinomial logit model.,$+ *$, and $* *$ indicate statistical significance at the 10,5 , and 1 percent level.

Source: $\quad$ Own calculations using Swiss Census 2000. 


\section{Appendix}

Table A1 Ordered Probit Estimation of Determinants of Child Educational Attainment

\begin{tabular}{ccc}
\hline & Natives & $\begin{array}{c}\text { Second Generation } \\
\text { Immigrants } \\
\text { Coef. } \\
\text { (Std. Error) }\end{array}$ \\
\hline
\end{tabular}

Parental Education

Father Low $(0 / 1)$

$\begin{array}{cc}-0.233^{* *} & -0.082^{*} \\ (0.026) & (0.034) \\ 0.553^{* *} & 0.426^{* *} \\ (0.025) & (0.036) \\ -0.271^{* *} & -0.213^{* *} \\ (0.018) & (0.030) \\ 0.512^{* *} & 0.379^{* *} \\ (0.030) & (0.034) \\ 0.079 & 0.163 \\ (0.114) & (0.140) \\ 0.545^{* *} & 0.412^{* *} \\ (0.087) & (0.134) \\ -0.216^{* *} & -0.171^{*} \\ (0.063) & (0.066) \\ -0.596^{* *} & -0.280^{* *} \\ (0.047) & (0.058)\end{array}$

\section{Household Characteristics}

Father Occ. Position: No training (0/1)

0.047

$0.186^{*}$

$(0.091)$

$(0.079)$

Father Occ. Position: Low qualified blue collar (0/1)

$-0.069$

$0.204 *$

$(0.085)$

$(0.082)$

Father Occ. Position: Low qualified white collar (0/1)

0.006

$0.173 *$

$(0.085)$

$(0.085)$

Father Occ. Position: Intermediate level occup. (0/1)

$0.167^{*}$

$0.339 * *$

$(0.084)$

$(0.079)$

Father Occ. Position: Other self employed (0/1)

0.077

$0.208 * *$

$(0.084)$

$(0.080)$

Father Occ. Position: Academic / upper mngmt. (0/1)

$0.309^{* *}$

$0.458 * *$

$(0.085)$

$(0.082)$

Father Occ. Position: Qualified self employed (0/1)

$0.337 * *$

$0.688^{* *}$

$(0.094)$

$(0.105)$

Father Occ. Position: Top management (0/1)

$0.316^{* *}$

$0.450 * *$

$(0.089)$

$(0.093)$

Father Occ. Position: Not employed (0/1)

$-0.104$

$0.165^{*}$

$(0.093)$

$(0.084)$

Father Occ. Position: Other (0/1)

0.052

$0.212 * *$

$(0.084)$

$(0.077)$

$0.086+$

0.061

Mother Occ. Position: No training (0/1)

$(0.048)$

(0.057) 
Mother Occ. Position: Low qualified blue collar (0/1)

Mother Occ. Position: Low qualified white collar (0/1)

Mother Occ. Position: Intermediate level occup. (0/1)

Mother Occ. Position: Other self employed (0/1)

Mother Occ. Position: Academic / upper mngmt.(0/1)

Mother Occ. Position: Qualified self employed (0/1)

Mother Occ. Position: Top management (0/1)

Mother Occ. Position: Not employed (0/1)

Mother Occ. Position: Other (0/1)

Father Age

Mother Age

One Sibling (0/1)

Two Siblings $(0 / 1)$

Three or more Siblings $(0 / 1)$

\section{Individual Characteristics}

Female $(0 / 1)$

Religion: Jewish (0/1)

Religion: Islamic (0/1)

Religion: Other or no denomination (0/1)

Religion: No response (0/1)

\section{Regional Characteristics}

Population Density

Cantonal Youth Unemployment Rate 1999

Region 2 (Mittelland) (0/1)

Region 3 (Northwestern Switzerland) (0/1)

$\begin{array}{cc}0.047 & 0.011 \\ (0.059) & (0.102) \\ 0.175^{* *} & 0.097+ \\ (0.045) & (0.057) \\ 0.456^{* *} & 0.268^{* *} \\ (0.046) & (0.062) \\ 0.213^{* *} & 0.034 \\ (0.049) & (0.069) \\ 0.388^{* *} & 0.370^{* *} \\ (0.060) & (0.081) \\ 0.359^{* *} & 0.529 * * \\ (0.111) & (0.155) \\ 0.293 * * & 0.126 \\ (0.090) & (0.119) \\ 0.142^{* *} & 0.051 \\ (0.045) & (0.054) \\ 0.136^{* *} & 0.034 \\ (0.045) & (0.055) \\ 0.005 * * & 0.003 \\ (0.002) & (0.002) \\ 0.015 * * & 0.015 * * \\ (0.002) & (0.002) \\ 0.004 & 0.000 \\ (0.023) & (0.036) \\ -0.019 & -0.064+ \\ (0.024) & (0.039) \\ -0.036 & -0.173 * * \\ (0.026) & (0.044) \\ & \end{array}$

$0.148 * *$

$0.185^{* *}$

$(0.011)$

$(0.019)$

$-0.116$

$-0.143$

$(0.158)$

$(0.118)$

$-0.493 * *$

$-0.119 *$

$(0.116)$

(0.052)

$0.054+$

$-0.032$

$(0.022)$

$(0.031)$

$-0.471 * *$

(0.051)

(0.077)

$\begin{array}{cc}0.627 & -0.190 \\ (0.429) & (0.473) \\ 0.085^{* *} & 0.079 * * \\ (0.015) & (0.028) \\ -0.132 * * & -0.215^{* *} \\ (0.027) & (0.049) \\ -0.240^{* *} & -0.298^{* *} \\ (0.03) & (0.055)\end{array}$


Region 4 (Zurich) (0/1)

Region 5 (Eastern Switzerland) (0/1)

Region 6 (Central Switzerland) (0/1)

$(0.033)$

(0.062)

$-0.115 * *$

$-0.252 * *$

(0.036)

$(0.073)$

Region 7 (Ticino) (0/1)

$0.402 * *$

$0.273 * *$

(0.039)

(0.047)

\section{Immigrant Characteristics}

At least one parent Swiss since at least 5 years $(0 / 1)$

At least one parent Swiss since up to 5 years $(0 / 1)$

Both Parents Not Swiss Citizens (0/1)

(0.051)

0.000

(0.029)

0.053

Country of origin: Africa (0/1)

$(0.085)$

Country of origin: Europe (0/1)

$-0.141 * *$

Country of origin: Southern Europe (0/1)

Country of origin: Western Asia (0/1)

$-0.045$

(0.034)

Country of origin: Latin America (0/1)

$(0.065)$

Country of origin: Latin America $(0 / 1)$

$-0.118+$

(0.066)

Country of origin: North America (0/1)

$-0.079$

$(0.083)$

Country of origin: Asia and Oceania (0/1)

$-0.003$

(0.06)

Country of origin: Other $(0 / 1)$

$-0.142+$

(0.086)

Main Language differs from cantonal language (0/1)

$-0.072+$

(0.038)

$-0.001$

Home country illiteracy rate

Home country illteracy rate missing $(0 / 1)$

$-0.136 * *$

$(0.041)$

Number highly educated co-ethnics by region

$-0.013 * *$

$(0.005)$

\begin{tabular}{lcc}
\hline Threshold Parameter 1 & $-0.245^{*}$ & -0.069 \\
Threshold Parameter 2 & $(0.129)$ & $(0.18)$ \\
& $2.029 * *$ & $1.707^{* *}$ \\
\hline Number of observations & $(0.129)$ & $(0.181)$ \\
Log Likelihood & 47,948 & 14,587 \\
\hline
\end{tabular}

Source: Own calculations using Swiss Census 2000.

Note: $* *, *$, and + indicate statistical significance at the 1,5 , and 10 percent level. 